\title{
Clinical use of acid steatocrit
}

Citation for published version (APA):

van den Neucker, A. M. (2001). Clinical use of acid steatocrit. [Doctoral Thesis, Maastricht University]. Universitaire Pers Maastricht. https://doi.org/10.26481/dis.20011122an

Document status and date:

Published: 01/01/2001

DOI:

10.26481/dis.20011122an

Document Version:

Publisher's PDF, also known as Version of record

\section{Please check the document version of this publication:}

- A submitted manuscript is the version of the article upon submission and before peer-review. There can be important differences between the submitted version and the official published version of record.

People interested in the research are advised to contact the author for the final version of the publication, or visit the DOI to the publisher's website.

- The final author version and the galley proof are versions of the publication after peer review.

- The final published version features the final layout of the paper including the volume, issue and page numbers.

Link to publication

\footnotetext{
General rights rights.

- You may freely distribute the URL identifying the publication in the public portal. please follow below link for the End User Agreement:

www.umlib.nl/taverne-license

Take down policy

If you believe that this document breaches copyright please contact us at:

repository@maastrichtuniversity.nl

providing details and we will investigate your claim.
}

Copyright and moral rights for the publications made accessible in the public portal are retained by the authors and/or other copyright owners and it is a condition of accessing publications that users recognise and abide by the legal requirements associated with these

- Users may download and print one copy of any publication from the public portal for the purpose of private study or research.

- You may not further distribute the material or use it for any profit-making activity or commercial gain

If the publication is distributed under the terms of Article $25 \mathrm{fa}$ of the Dutch Copyright Act, indicated by the "Taverne" license above, 


\section{Clinical Use of Acid Steatocrit}


Cover: Detall of "Children's Games" of Pieter Bnegel de Ondere, Kunshistorisches Museum Vienna

English correction of the Incroduction, Discussion and Condusion by Mr. B. Wilkinson, Worldneh / Talencentum UM

Darawyse/ Universitaire Pers Mastricht

ISBN 9052783241

(C) A.M. Van den Neucker, Lanaken - Belgie 2001 


\title{
CLINICAL USE OF ACID STEATOCRIT
}

\section{PROEFSCHRIFT}

ter verkrijging van de graad van doctor aan de Universiteit Maastricht, op gezag van de Rector Magnificus,

Prof.dr. A.C. Nieuwenhuijzen Kruseman, volgens het besluit van het College van Decanen, in het openbaar te verdedigen op donderdag 22 november 2001 om 14.00 uur

\author{
door
}

Anita Maria Van den Neucker

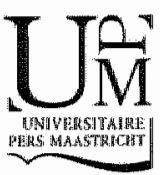


Promotor

Prof.dr.R.A.M.G. Donckerwolcke

Co-promotores

Dr. P. Pli. Forget

Dr. B. van Kreel

\section{Beoordelingscommissie}

Prof.dr. M.P. van Diejen-Visser (voorzitter)

Dr. W. Hameeteman

Prof.dr. E. Robberecht (Universitair Ziekenhuis, Gent, België)

Dr. M. Sinaasappel (Sophia Kinderziekenhuis, Rotterdam)

Prof.dr. R. W. Stockbrigger 
Leva in signum super nos lamen wultus Tui Psalk 4

Voor mijn macder. ter nagedachtenis an mijn vader. 


\section{CONTENTS}

CHAPTER 1 Introduction.

Lipid metabolism

Lipid malabsorprion

Methods for determination of faecal lipids

Chemical merhods

Gravimerric method

Titrimetric method of Van de Kamer

Method of Jeejeebhoy

Microscopic examination of stool specimen for fat droplets

Near-infrared reflectance analysis

NMR

Steatocrit

Fat absorption tests

Triglycerides in the serum / Fatty meal test

Beta-carotene

Vitamin $A$

Radioactive and isotope labeled fat absorption tests

References

Ain of the thesis

CHAPTER 2 The acid steatocrit: a much improved method.

J Paediatr Gastroenterol nutr 1994; 19:299- 303.

CHAPTER 3 Comparison of near infrared reflectance analysis of fecal fat, nitrogen and water with conventional methods, and fecal energy conrent.

(submirted) 
CHAPTER 4 Lipid, nitrogen, water and energy content of a single stool sample in healthy children and children with cystic fibrosis. 47 (submirted)

CHAPTER 5 Acid steatocrit during infancy.

CHAPTER 6 Clinical use of acid steatocrit. Acta Paediatr 1997; 86:466-9.

CHAPTER 7 Acid steatocrit a reliable screening tool for steatorrhoea. Acta Paediarrica 2001; 90:1-3

CHAPTER 8 Discussion and conclusion.

SUMMARY

SAMENVATTING

DANKWOORD 



\section{CHAPTER 1}

\section{Introduction}

Obesity is considered the most common health problem of the new millennium (1) and vascular diseases are the main cause of death (2). Nutrirional lipids, considered to be the most important contributing factor to these diseases, are not popular among nutritionists $(3,4)$, while fat is the cream of our food and gives taste to it (5).

Lipids are essential for the nutrition of children, not only as a source of essential fatty acids $(6,7)$ and as a vehicle for lipid soluble vitamins, but mostly to provide sufficient nutritional energy. Lipids are important for cellular metabolic processes as well as for cell membrane composition, fluidity, peroxidation, prostaglandin and leukotriene synthesis. Further, lipids are implicated in the mechanisms of brain development, inflammatory processes, atherosclerosis, carcinogenesis, ageing and cell renewal $(8,9)$. Children will fail to thrive if the intake, digestion or absorption of lipids is insufficient; therefore dietary fat restriction is not recommended in infancy $(10,11,12)$.

While the intake of lipids is easy to callculate (13), the evaluation of lipid digestion and absorption is more laborious. Different laboratory techniques have been designed to assess fat absorprion $(14,15)$.

At present, the gold standard to evaluate fat absorption is the fat balance technique, based on fat intake and faecal fat excretion and expressed as fat absorption coefficient. Faecal fat is usually determined by the titrimetric method as described by Van de Kamer in 1949 (16). This method is laborious and unpleasant for patients and laboratory staff and for this reason more simplified techniques have been proposed $(17,18,19,20,21)$.

Before describing those various techniques, it is worth giving a short review on lipid absorption and malabsorption to allow adequate interpretation of the results obtained by these different methods. 


\section{Lipid Metabolism}

Fats in the human dier consist of triglycerides, phospholipids, and cholesterol. Approximately $97 \%$ of dietary lipids consist of triglycerides (9). Each triglyceride molecule consists of three farty acids esterified to one molecule of glycerol. The fatry acid chains have different chain lengths and different degrees of saturation.

Figure 1. Triglyceride molecule with stereospecific numbering (sn) of the $\mathrm{C}$-atoms of the glycerol-part; $\mathbb{R}=$ hydrocatbon chain.

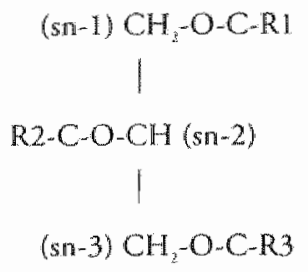

Other dietary lipids are phospholipids, free fatry acids (FFA), mono- and diglycerides (MAG, DAG), cholesterol and cholesterolesters; cholesterol is the main dietary sterol (22).

After ingestion, lipids must be digested before absorption in the intestine and metabolization by the liver. The digestion of lipids can be described as a chain of events: emulsification, lipolysis, solubilisation, and uptake into the enterocyte, reesterification in the enterocyte and transport via the lymph into the circulation (fig 2).

Figure 2.

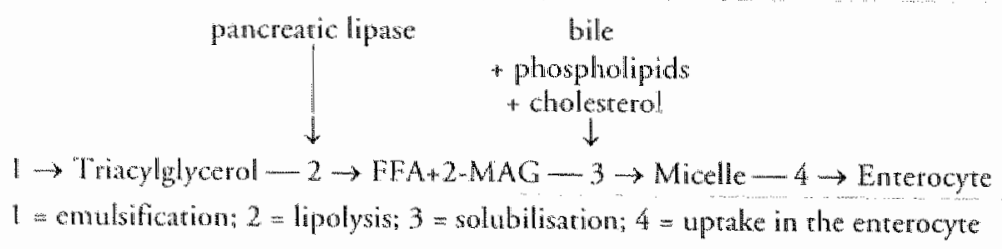

Defects at any level of the lipid metabolism can cause steatorrhoea, defined as an excess of faecal fat. Faecal lipids originate normally from unabsorbed dietary fat and for a small part from bacteria and from endogenous sources such as bile and 
breakdown of desquamated epithelial cells (23). In childhood the normal amount of faecal fat depends on the age of the child. In adults faecal fat exceeding $6 \mathrm{~g}$ per day is considered abnormal. Daily faecal fat excretion in normal children ranges between $1.3 \mathrm{~g}$ and $3.8 \mathrm{~g}$ with a fat absorption coefficient greater than $95 \%$. The fat absorption coefficient of infants younger than 9-10 months ranges from $80-90 \%$ and these higher faecal far losses are considered to be normal at this age $(24,25,26,27,28)$.

\section{Emulsification}

After ingestion dietary lipids are emulsified by chewing, peristaltic movements of the stomach and forceful transport through the pyloric channel into the duodenum. Chemical modification by lingual and gastric lipase adds to the emulsification (22).

\section{Lipolysis}

Lipolysis is the result of the interaction of different enzymes on dietary lipid; some enzymes are secreted as pro-enzyme and have to be acrivared, orhers work in combination with bile acids (table 1). Different synonyms for these enzymes are reported in the literature (29).

Table 1. Enzymes involwed in lipolysis $(30,31,32,33,34,35)$.

\begin{tabular}{llll}
\hline Sontce & Enzyme & Activator & Main substrate \\
Mammary gland & Carboxyl esrer lipase & Bile salts & Monoglyceridest \\
& & & cholesterylester \\
Lingual glands & Lingual lipase & - & Triglycerides \\
Stomads & Gastric lipase & - & Triglycerides \\
Pancreas & Co-lipase & Trypsin & Fat droplets \\
& Pancreatic lipase & - & Triglycerides \\
& Carboxyl ester lipase & Bilesalts & Cholesterylester \\
& Phospholipase A.2 & Trypsin & Phospholipids
\end{tabular}

Digestion of lipid starts in the stomach with hydrolysis by acid lipases, called pre-duodenal lipases also known as lingual, salivary, pharyngeal, gastric lipase and pre-gastric esterase $(32,36)$.

Duodenal hydrolysis of dietary lipids is carried out by pancrearic co-lipase-dependent lipase, carboxyl ester hydrolase and phospholipase A2; the structure of those enzymes has recently been described $(33,34,35)$.

Pancreatic lipase acts in the duodenum in collaboration with bile acids (34). Co-lipase is secreted by the pancreas as a pro-enzyme. Co-lipase has affinity for 
bile acid micelles as well as for phospholipid covered emulsion. The pancreatic lipase-co-lipase interaction is still a matrer of intensive study (33).

Carboxyl ester hydrolase, known as cholesterol esterase, is also acrivated by bile acids. It is believed that this enzyme is only active in the upper intestine. Carboxyl ester hydrolase is secreted by the exocrine pancreas and the mammary gland and is also detectable in human milk (30). Carboxyl ester hydrolase hydrolyses sn-2 monoglycerides, which originate from lipolysis by pancreatic lipase in the inrestinal lumen, and completes in this manner the hydrolysis of triacylglycerols $(37,36)$.

Phospholipids are the substrate for phospholipase A2. Phospholipase A2 is secreted by the pancreas as pro-enzyme and is activared in the intestinal lumen by tryptic cleavage $(38,39)$.

\section{Transport of lipids from intestinal lumen to the enterocyte}

After hydrolysis of lipids, free fatty acids and monoglycerides are absorbed from the intestinall lumen. The duodenum and jejunum are the intestinal segments where fat absorption occurs, while most ingested fat is absorbed by the mid-jejunum (39). For long chain fatty acids and cholesterol, passage across the unstirred water layer is rate limiting, whereas passage of shorr and medium chain fatty acids is limited by the brush border membrane (8). Bile acids are necessary for the absorption of lipids by increasing their solubility into the unstirred water layer. Nearly all bile acids have a hydrophobic site and a hydrophylic site (40). The hydrophobic sire binds to the lipids and surrounds them with a hydrophylic wall by forming micelles: bilayer discs with a lipid core and a hydrophylic surrounding which makes them soluble in water (22). The lipids migrate through the unstirred water layer and through the cell membrane. This transport is not yer elucidated but it is accepted that lipids migrate through this water layer as micelles, and then reach the cell membrane followed by passive transport through the membrane. Some investigators, however, mention active transport of lipids by a specific protein in the jejunal enterocyte, the MVM-FABP (micro villous membrane fatry acid binding protein) $(31,41)$.

\section{Lipid metabolisn in the enterocyte}

In the enterocyte rhe free fatty acids bind to the intestinal fatry acid binding protein (I-FABP), and cholesterol, monoglycerides, lysophosphatides as well as faty acids bind to the liver farty acid binding protein (L-FABP). Both proteins exist in the cytosol of epthelial cells of the upper small intestine. I-FABP was first isolated from the intestine, while L-FABP was first found in the liver. Cholesterol and other sterols bind to two isoforms of sterol carriet proteins, SCP-1 and SCP-2. Binding of lipids to intracellular binding proteins may prevent lipids 
from forming oil droplets in the cytosol and transport lipids from the brush border to the smooth endoplasmic reticulum. In the smooth endoplasmic reticulum monoglycerides are re-esterified into triacylglycerols, lysophospholipids are re-converted to phospholipids and cholesterol is re-esterifted, although some free cholesterol remains. The reprocessed lipids, along with the new lipids that are synthesized in the epithelial cell, accumulate in the smooth endoplasmic reticulum. Phospholipids tend to cover the external surfaces of these lipid droplets with their polar head groups toward the aqueous exterior. These lipid droplets are known as pre-chylomicrons. These droplets fuse with the lipoprotein precultsor released from the ribosomes and chylomicrons originate. Chylomicrons, lipid globules, migrate to the basolateral side of the enterocyte where they are secreted into the interstitial fluid and reach the bloodstream via the lymph. The exit phase of lipid absorprion is still incompletely understood (8).

The lipoprotein precursor is a dense emulsion particle originating from the apoB synthesizing ribosomes by translation of the amino-terminal of apoB in combination with microsomal triglyceride transfer protein (MTP) that continues to be enlarged during translation. In the absence of MTP, apoB is translated without undergoing lipidation. Moreover underlipidated particles are generated that are too small to accommodate the proper folding of apo-B. Misfolded apoB is degraded mainly by the ubiquitin-proteasome pathway. Other proteolytic systems of the endoplasmic reticulum and other post-endoplasmic reticulum compartments are also involved in the presecretory degradation of apoB. This results in accumularion of fat in the enterocyte and causes lipid malabsorption. (42).

\section{Lipid malabsorption}

Lipid malabsorption can occur when there is a disturbance in either lipid digestion or absorption. Lipid digestion and absorption are the result of the interaction of various complicated mechanisms as described above. Different causes can be responsible for lipid malabsorption, of which the most importanr are: bile deficiency, pancreatic insufficiency and mucosal atrophy.

Even with severe malabsorption there always remains some degree of absorption because of the complexity of lipid digestion and the presence of alternative absorptive pathways (39). Severe fat malabsorption, however, results in malnutrition, in vitamin or essential fatry acid deficiency (8). The diseases most frequently associated with lipid malabsorption in childhood are cystic fibrosis, celiac disease and disturbances in bile acid metabolism due to cholestasis or interrupted. enterohepatic circulation. 
Fat that is not absorbed leaves the intestines with the stools and gives them a greasy colour or constitutes somerimes an oil phase distinct from, or surrounding, otherwise normal stools $(43,44)$. When the amount of faecal fat exceeds a certain level, depending on the age of the child, it is called steatorrhoea $(25,26,27)$. Different causes of steatorrhoea are listed in table 2 according to the localization of the defect in fat maldigestion and malabsorption, and in table 3 according to different diseases. Sometimes there are different causes in one disease responsible for the fat malabsorption e.g. in patients with untreated celiac disease the fat malabsorption may be due to both the reduced lipid absorption because of villous atrophy and to exocrine pancrearic insufficiency (45). In cystic fibrosis fat malabsorption may be due to exocrine pancreatic insuffuciency, to absorption problems through the unstirred water layer, and if associated liver disease is present, to bile salt deficiency (46).

Table 2. Defects leading ro stearothoea $\mathrm{H}:(44)$

Defect of lipolysis

Defect of forming of micelles

Deffect of absorprion in the enterocyte

Defect in the re-sterification

Defect in the chylomicron release into the lymphatics.

Table 3. Causes of steatorhoea II: (47)

Small intestinal abnormalities:

Anatomic abnormalities:

Intestinal matrotation

Arresia

Stenosis

Web

Duplicarion

Short bowel syndrome

Intestinal Lymphangiecrasia

Inflammation

Microbial overgrowth

Anaerobes

Parastes: Giardia lumblia

Regional onteritis

Merabolic disorders

Aberalipoproteinemia

Acrodematicis enteropathica 
Immunologic disorders

Agammaglobulinemia

Hypogammaglobulinemia

Dysgammalobulinemia

Thymic displasia

Apha chain disease

Nodular lymphoid hyperplasia of the small intesrine

Sensitivity reactions

Milk protein sensitivity

Soybean protein sensitivity

Alergic gastroenceropathy

Transient gluren inrolerance

Drugs

Antibiotics. neomycine

kanamycine

Paraminosalicylic acid

Calcium carbonate

Cathartics (podophylin)

Cholestyramine

Colchicine

Methotrexate

Miscellancous

Celiac disease

"Tropicall sprue

Intractable diar rhoea of infancy

Protein-calorie malnutrition

Intestinal lymphoma

Exocrine pancreatic insufficiency:

Generalized pancreatic insufficiency

Cystic fobrowis.

Schwachnan-Diamond syndrome

Congenitall rubellat

Chronic pancreatitis / relapsing acute pancreatitis

Familial heredirary pancreatitis

Protein-caloric malnutrition

Isolated enzyme deficiencies

Lipase deficiency

Trypsinogen deficiency

Enterokinase deficiency

Liver disease

Cirrhosis

Hepatitis

Biliary atresia 
Steatorrhoea is the result of lipid malabsorption and this can be measured, irrespective of the cause of steatorrhoea. For the diagnosis of steatorrhoea the amount of faecal fat has to be measured quantitatively or semi-quantitatively. Some investigators believe that the eye of a good clinician, the weight of the daily stool or the faecal water content allows a diagnosis of steatorrhoea. The majority of clinicians, however prefer to rely on the results of the faecal fat balance for the diagnosis of steatorrhoea $(16,44,48,49)$.

The faecal fat balance technique is still considered the gold standard for the diagnosis of fat malabsorption $(16,25)$. The oral fat intake of at least 3 days (some authors recommend 5 or 6 days) has to be recorded. The total faecal excretion has to be collected during this recorded period and frozen at $-18^{\circ} \mathrm{C}$. All collected stools have to be homogenized thoroughly and the faecal fat content determined by the method of Van de Kamer. The fat absorption coefficient is calculated by the following equation and expressed as a percentage:

$$
\frac{\text { ingested fat }(\mathrm{g} / \text { day })-\text { excreted fat }(\mathrm{g} / \text { day })}{\text { ingested fat }(\mathrm{g} / \text { day })} \times 100
$$

This merhod is laborious and unpleasant for patients and for laboratory personnel. Furthermore, there are many possibilities for inaccuracies. First, oral fat intake has to be recorded carefully during 3 or more days. The total faecal production during this 3-day period has to be collected thoroughly. This can be managed by the use of a non-absorbable dye at the start and at the end of the collection period. The total amount of stools berween the appearance of these two markers has to be collected. This 3-day stool collection is necessary to minimize the normal daily variation in fat absorption (25). During this collection period a minimal $(>80 \mathrm{~g} / \mathrm{day})$ and constant daily fat intake is necessary. Normal daily faecal fat output is 1 to $2 \mathrm{~g} /$ day due to endogenous fat excretion even without oral fat intalke $(23,44)$. With far mallabsorption a small increase of dietary fat will result in steatorrhoea, whereas in patients with normal fat absorption a rise in dietary fat will have no influence on the faecal fat excretion $(50,51)$

In his thesis in 1950 Weijers had already mentioned many difficulties associated with the faecal far balance technique and described a way of collecting faecal material in infants and young children while staying in hospital and using a pot specially made for this purpose (21). The main problem at that time, however, was the lack of a rapid method for faecal far determination.

Since the incroduction in 1949 of the ritrimetric method of Van de Kamer for the measurement of faecal fat, the faecal fat balance technique gained popularity 
(12). But the collection of stools of infants and children today is as difficult as it was at that time, and the determination of faecal fat by the method of Van de Kamer is as laborious as it was in 1949. Parients and parents are unwilling to collect stools. For these reasons new methods for evaluating steatorrhoea are desired.

A break-through came with the idea that faecal fat concentration could give clinically useful information on the etiology of steatorrhoea. In 1984 Bo-Linn and Fordtran suggested that faecal fat concentration could differentiate steatorrhoea due to pancreatic insufficiency from that due to intestinal abnormalities (52). For this purpose they used 48 or 72-hour stool collections. In 1987 Pederson et al. demonstrated that the faecal fat concentration in a random stool sample gave the same clinical information as the 3-day faecal fat excretion (53). Other investigators subsequently demonstrated that measurement of faecal fat concentration could give similar information as a 3-day stool collection, and this initiated the use of simpler tests to screen, diagnose and monitor fat malabsorption in clinical practice $(54,55,56)$. However to assess the absorption coefficient, the 72 -hour balance technique remains indispensable.

\section{Methods for the determination of faecal lipids}

\section{Chemical methods}

\section{Gravimetric determination of total faecal fat}

In this method a pre-weighed, emulsified stool specimen is acidified to decrease the ionisation of fatty acids (present as free acids, or soaps). The lipids are then extracted from the stool specimen with an organic solvent, the supernatant evaporated, and the residue measured by gravimetry (57). By this method $98-99 \%$ of the fat is extracted (28). This method is laborious and rime consuming and fat extraction depends on the solvent $(16,44)$

\section{Titrimetric method of Van de Kamer (16)}

In 1949 Van de Kamer described a chemical method for determining faecal fat on wer faeces; faeces are saponified with porassium hydroxide in ethanol, hydrochloric acid is added ro the solution and fatry acids are liberated. Ethanol is then added and fatty acids are exiracted with petrolleum ether. After shaking of the homogenate, there is a delineation in different layers. The fatty acids in the perroleum ether layer are subsequently titrated with alkali. This method was at that time an improvement on the existing methods, but is nowadays considered imprecise, complex, tedious and time consuming (58). Eighty percent of total faecal lipids are determined by this method (28). 
The method described by Jeejeebhoy in 1970 gives a better fat recovery compared to the method of Van de Kamer. Through the use of a different solvent $99 \%$ of faecal lipids are extracred $(28,59)$.

\section{Microscopic exumination of the stool specimen for fat droplets}

In patients with steatorrhoea the microscopic examination of stool reveals fat droplets. This test can be performed by mixing a small amount of stool with several drops of water or Sudan red stain. Drummy et al. showed a correlation between the diameter of the fat globules and the total faecal lipids (18). But this good correlation exists mainly when there is severe steatorrhoea, and is less evident in patients with moderate steatorrhoea (25). This method is more qualitative than quantitative, but Khouri et al have ameliorated the Sudan stain by acidification and heating and concluded that they provided specific quantitative information about the faecal fat content (60). Some investigators have reported favourably about this test, but others have not $(44,61,62)$.

\section{The near-infrared reflectance analysis}

The near-infrared reflectance analysis is based on the measurement of radiation in the near-infrared spectrum scattered by the surface of a spot faecal sample (63). The reflectance is matrix and substrate specific; the components measured have typical functional groups $(\mathrm{CH}, \mathrm{NH}, \mathrm{OH}$...) with specific absorption bands in the near-infrared range $(700-2500 \mathrm{~nm})$. It is possible to determine dry weight, total nitrogen, total fat and hydrolyzed fat on a faecal sample in a few minutes. Although the manufacturer recommends no homogenization of the faecal sample, this is necessary since the reflectance is marrix specific. Another difficultry with this method is the need to perform one's own calibration curve $(44,58)$. Furthermore the cost of the apparatus is high, but that of personnel is low. Several investigators consider this method as a good alternative for the chemical determination of faecal fat in a stool sample $(20,21,64,65,66)$.

\section{NMR}

Fat is the only liquid component of lyophilized faecal material after heating at $80^{\circ} \mathrm{C}$. It is possible to measure this fat by nuclear magnetic resonance. This method is used in the food industry, but the costs, and preparation of the material makes it unsuitable for clinical use $(44,67)$.

\section{The stetactorit}

While searching for a simple and easy test to quantify faecal fat, Phuapradit described the steatocrit method in 1981 (19). The method resembles the haematocrit method, as the name indicates. Faeces diluted with deionized water is mixed, homogenized and sucked in a capillary tube and centrifuged in a 
haematocrit centrifuge. After centrifugarion, three layers are separated: a solid layer, a water layer and a fat layer at the top. The result is calculated by:

$$
\frac{\text { length of far layer }(\mathrm{mm})}{\text { length of far layer }(\mathrm{mm})+\text { length of solid layer }(\mathrm{mm})} \times 100
$$

Colombo et al. and Gurarino et al. were inirially enthusiastic about this cheap, easy and simple test, but soon Walters et al. reported the inability to reproduce these results $(68,69,70)$. Others reported the difficulty to measure the lengths of the different layers, because of the lack of sharp delineation and tried ro ameliorate the test by adding Sudan stain and using a dial calliper (71). This problem may be solved by acidification of the homogenate: the acid srearocrit method (72). Acidification of the faecal material is a technique frequently used in methods determining faecal fat: Van de Kamer added HCL to the mixture after saponifying faecal fat (16). Furthermore, Bertinardi demonstrated that the rype of faecal fat influences the results of the steatocrit and that acidification can overcome this problem (73). Also other investigators have confirmed this methodological improvement (74).

\section{Fat absorption tests}

All the tests reported above measure the result of fat malabsorption by evaluation of faecal far loss. The following tests evaluate fat absorption by measuring absorbed lipids or fat-soluble products:

\section{Trighlycerides in the serum / Fatty meal test}

Determination of triglycerides or chylomicrons in the serum before and after a meal gives an idea about the absorption of far. The serum triglycerides are determined with the aid of nephelomery: estimations of light scattering performed on blood plasma (28).

Jonas et al. described an oral fat loading test for children. After a 6 -hour fast in small children and a 12-hour fast in older ones, a meal consisting of fat (Blue Band margarine) $2 \mathrm{~g} / \mathrm{kg}$ is given to the children, orally or by nasogastric tube in babies or reluctant toddlers. Blood is sampled at periods of $0,2,4$ hours after fat ingestion. Plasma trigyceride levels is determined fluorimetrically (75).

This is a semi-quantitative method and several other factors besides fat digestion and absorption interfere with the results: e.g. the amount and type of fat ingested and the emprying rate of the stomach. This technique is therefore mostly consid-ered not quantitative enough, but is still used by several authors in addition to orher tests $(25,73,76)$. 


\section{Beta-carotene test}

The determination of beta-carotene, a precursor of vitamin $A_{3}$ a fat-soluble vitamin, is a simple test based on the fact that a disturbed fat absorption influences the beta-carotene absorption. This test is however an indirect test with possible interference of liver diseases, as beta-carotene is converted to vitamin $\mathrm{A}$ in the liver (28). Furthermore, there is an important intra- and inter-individual variation in measurement of beta-carotene in plasma $(44,77)$.

\section{Vitumin A test}

Vitamin $A$ is a fat-soluble vitamin, and on the assumption that vitamin A metabolism parallels fat merabolism, a vitamin $A$ loading test was designed. A doses of $10.000 \mathrm{IU}$ vitamin $\mathrm{A}$ per $\mathrm{kg}$ body weight is given orally and vitamin $\mathrm{A}$ is determined in the plasma before and $3 / 2$ and 7 hours afrer ingestion. The association with lipid metabolism is however not so clear and the correlation with fac absorption is poor (25). Furthermore, vitamin $A$ serum levels appear to be controlled by intestinal regularion. Vitamin $A$ is not passively absorbed with fat and the relation with the lipid metabolism is not so strict $(28,78)$.

\section{Radioactive and isotope labeled fat absorption tests}

Fat labelled with radioactive- markers or isotopes in particular ${ }^{14} \mathrm{C}$ and ${ }^{13} \mathrm{C}$-enriched triglycerides and ${ }^{13} \mathrm{C}$-cholesteryl ester were used to study lipolysis. For ethical reasons radioactive ${ }^{14} \mathrm{C}$-labelled fat is not used in infants and children. In 1989 Vantrappen et al. introduced 'The mixed triglyceride breath test' as a non-invasive test of pancreas lipase activity in the duodenum (14). ${ }^{13} \mathrm{C}$-marked triglycerides, which contain a ${ }^{13} \mathrm{C}$-marked medium chain fatty acid in the 2 position and long-chain fatty acids in the 1 and 3 position (1,3-distearyl,2 [carboxyl- ${ }^{13} \mathrm{C}$ ] octanoyl glycerol), is given orally. The 2 stearyl groups are split by lipolysis and the octanoyl group is metabolized after absorption into ${ }^{13} \mathrm{CO}_{2}$, which can be measured in the breath. Breath samples are taken before and every 30 min after a ${ }^{13} \mathrm{C}$-enriched meal for 5 hours and ${ }^{13} \mathrm{CO}_{2}$ is measured in the expired air by mass-spectrometry. When lipolysis fails, the triglycerides are not split and are eliminated by the stools, and the amount of recovered ${ }^{13} \mathrm{CO}_{2}$ is reduced $(14,44,79,80)$. Although this test is safe, non-invasive and useful in the study of lipolysis, the results are dependent on the different steps of lipid metabolism in the enterocyte and in the liver. Pulmonary problems or endogenous $\mathrm{CO}_{2}$ production may also influence the test. For these reasons and because of the difficuly of collecting breath samples and the cost of detecting the isotope, this test is not often used for routine clinical purposes $(43,62,81,82,83,84)$. 


\section{References}

1. Martinez JA. Obesiry in young Europeans: generic and environmental infuences. Eur J Clin Nurr 2000 Mar; 54 Suppl 1: 56-60.

2. Dobson A J, Evans A, Ferrario M, Kuulasma KA. Moltchanov V A, Sars S. Tunstall Pedoe H. Tuomilehro J O Wedel H, Yanell J. Changes in estimated coronary risk in the 1980s: datm from 38 popularions in the WO-Monica Project. World Health Organisation. Monitoring trends and determinants in cardiovascular diseases. Ann Med 1998; 30: 199-205.

3. WHO Study Group. Dier, nurrition and the prevention of chronic diseases. WHO Ted Rep Ser 797, Genewa: WHO 1990.

4. Milmer J A, Allison R G. The role of dietary fat in chuld nutrition and development: summary of an ASNS workshop. J Nur; 1999; 129: 2094-2105.

5. Drewnowski A. Energy density, palatability, and sathery: implications for weight control. Nutr Rev 1998 Dec; 56 (12);347-53.

6. Makrides M, Neumann M, Simmer K. Parer J, Gibson R. Are long-chain polynusaturated Gatty acids essential nutrients in infancy? Lancer; 1995 June; 10; 1463-68.

7. Hornstra G. Essential fatty acids in mothers and their neonates. Am J Chin Nutr $2000 \mathrm{May} 71$ (5 Suppl): 1262-95.

8. Kolerso $B$, Demmelmair $H$, Socha P. Nutritional support of infants and childrent supply and meabolism of lipids. Ballieres Clin Gascroenterol 1998; 12 (4):671-96.

9. Thomson AB, Schoeller C, Keelan M, Smith L, Clandinin MT. Lipid absorption: passing through the unstirred layers, bush-border membrane, and beyond. Can J Physiol Pharmacol 1.993: $71(8): 531-55$.

10. Keinmann $\mathrm{R}$. Tawards a 'new beginning' dierary fat restrictions in infancy? Acta Paediatr $2000 ; 89: 2-3$.

11. Kolerko B. Response to and range of acceptable far intakes in infants and children. Eur I Clin Nucr 1999; $53:$ S78-83.

12. Koletzo B. Lipid supply and metabolism in infancy. Curr Opin Clin Nur Metab Care 1998; $1(2): 171-7$.

13. Nederlandse voedingsmiddelentabel. Voorlichtingsburea woor voeding 1999.

14. Wantrappen G R, Rurgeers P J, Ghoos Y F. Hiele M I. Mixed wiglyceridebreath rest: a non invasive test of pancreatic lipase activity in the duodenum. Gastroenterology $1989,96: 1126-34$.

15. Goldsein $\mathrm{R}$, Blondheim $\mathrm{O}$, Levy $\mathbb{E}$, Stankicwict $\mathrm{H}$, Freier $S$. The tatry meal test an altermative to srool fat analysis. An J Clin Nutr 1983: 38:76,3-8.

16. Wan de Kamer JH. Huinink HV, Weyers HA. Rapid method for the detemination of fat in $\mathrm{f}$ ces. J Biol Chem 1949: 177:347.55.

17. Farrison GA, Sheldon WH. Faecal Gatanases in children. Arch Dis Child 1926;2:338.48.

18. Drummey GD. Benson JA. Jones CM. Microscopical examination of the stool for steatorthea. NEngl Med 1961; 264:85-7.

19. Phuapradic P. Narang A, Mendonca P. Harris DA, Baum J D. The steatocrita ample method for estimating stod fat conrent in newborn infants. Arch Dis Child 1981;56:725.7.

20. Fales FW. Evaluation of a spectrophotomeric metod for deremination of rotaf fecal lipid. Clin Chem 1971:11:1103-8,

21. Benini L, Caliari S, Guidi GC, Vaona B, Tallami G, Vantini I and Scuro LA. Near infared spectromery for faecal far measurement: comparison with conventional gavimerric and titrimetric nethods. Gur 1989:30: 1344-47. 
22. Dewlin T M (1997). Textbook of biochemistry, $4^{\text {th }}$ ed. Willey a sons. inc. New York.

23. Comperz $\$ \mathrm{M}$, Sammons $\mathrm{H}$ G. The origin of faecal lipids, the composition of faecal fars in humari subjects. Clin Chim Acx; 1963; 8: 591-603.

24. Whliams H H, Endicom EN, Shepherd M L, Galbraith H, Macy IG. Fat excrerion by normal Children. J of Nutrion $1943 ; 25: 379-87$.

25. Weiters $H$ A. Fat absorption in normal and abnormal infants and children. Thesis 1950 Ureche The Netherlands.

26. Shmerling D H. Forrer J C W, Prader B S C, Prader A. Fecal fat and nitrogen in healthy children and in children with malabsorption or maldigestion. Pediatrics 1970;46:690-95.

27. Fraisse F, Schmitz J, Rey J. Wormal walues of the main stool consrituents from age 1 year to puberty. Arch Fr Pediatr 1981; 38: 667-70.

28. Buttis C A, Ashwood E R (1999). Therz Textbook of Clinical Chemistry; $3^{\text {th }}$ ed. Philadelphiat, Pensylvenia, USA.

29. Verkade H J. Lipid Absorption and merabolism. Thesis; 1993 ; Groningen The Netherlands.

30. Hamosh M. Lipid Merabolism in premature infants. Biol Neonate 1987; 52 (suppl 1): 50-64.

31. Berne R M, Levy M N. Physiology (1998): $4^{\text {hh }}$ ed. Mosby Inc. St Louis, Missouri, USA.

32. Canaan $\$$, Roussel A, Verger R, Cambillaw C. Gastric Lipase: crystal structure and activity. Biochim Biophys Acrat 1441; 197-204.

33. Tibeurgh van $H$, Bezxine $\$$, Cambillat $C$, Verger $\mathbb{R}$, Carriene $F$. Colipase: stucture and interacrion with pancreatic lipase. Biochim Biophys Acta 1999; 1441: 173-84.

34. Lidberg U, Kannius-Janson M, Nilsson J, Bjursell G. Transcriptional regulation of the human carboxyl ester lipase gene in exocrine pancreas. Evidence for an uque tissue-specific en hancer. J Brol Chem 1998; 273:31417-26.

35. Yuan C, Tsai M-D. Pancrearic phospholipase A2: new views on old issues. Biochim Bioplys Acta 1441; 215-22.

36. Carricre D, Barrowman I A, Verger R, Laugier R. Secretion and contribution to lipolysis of gastric and pancreatic lipases during a test meal in humans. Gastroenterology 1993; 105 : 876-888.

37. Hernell O, Bläckberg L Digestion of human lipids: physiologic significance of sn-2 monoacyl glycerol thydrolysis by bile salt-stimulated lipase. Pediatr Res $1982 ; 16 ; 882-5$.

38. Desnuelle P'. Sjostrom H. Norén O (1986). Molecular and Cellular Basis of Digestion. UIseviers Science Publishers BV, Amsterdam.

39. Gationg W F (1999). Review of Medical Physiology. Appleton \& Lange, Sramford USA.

40. Agetlon 1. B, Torchia E C. Intracellular transport of bile acids. Biochim Biophys Acta 2000; $1486: 198209$.

41. Stemmel W, Lotz G, Strohmeyer G, Berk P D. Identificarion, isolation, and partial characterisation of a farty acid binding protein from rat jejunal nicrovillus membranes. J Clin Invest $1085 ; 75: 1068-76$

42. Davidson N O. Shelness G S. Apolipoprotein B: mRNA editing, lipoprotein assembly, and presecterory degradation. Annu Rev Nutr 2000; 20: 169-93.

43. Walker, Durie, Hamilton, Walker-Smith, Watkins (2000). Pediatric Gastrointestinal Disease. B. C Decker lnc. Ontario Canada.

44. Lembke B, Braden B, Stein I. Diagnosis of Steatorhea. Z Gastroenterol 1994; 32(5): 256-61.

45. Nousia-Arraniakis $S$, Karagiozoglou-Lamboudes T. Aggouridaki C, Malaka-Lambrellis E, Galli-Tsinopoulou A, Xefteri M. Influence of jejunal morphology changes on exocrine pancreatic function in celiac disease. I Pediatr Gastroenterol Nutr 1999; 29; $81-5$. 
46. Kaliwanakis M, Minich D M, Bijleweld CM A, Aalderen wan W M C, Stellaard F. Laseur M, Vonk R, Verkade H J. Far malabsorprion in cystic fbrosis parients receining engme replace. ment therapy is due to impared intestinal uptake of long-chain fatry acids. Am J Clin Nut $1999: 69: 127-34$

47. Lebenthal $\mathbb{E}$ (1989) Textbook of Gastroenterology and Nutrition; second ad. Raven Press; New York.

48. De Curris $M$, Kempson C, Ventura V, Canter $N$, Mclntosh $N$. The ralationship bewween fecal fat and water in very low bith weight infants. ] Pediatr Gastroenterol Nurr 1990; 11:63-5.

49. Thirup P. Stearorthea cannor be excluded where there is a fecal weigh below $0.200 \mathrm{~kg}$ per day and a high fecal consistency. Scand J Clon Lab Invest 1998; 58(7):577 83.

50. Kasper H. Faccal fat excrerion, diarhea, and subjective complaints with highly dosed oral fat intake. Digestion 1970; $3: 321-30$.

51. Hill E, Bloor W R. Fat excretion. J Biol Chem 1922; 53:1711-8.

52. Bo-Linn $\mathrm{G}$ W, Fordtran J S. Fecal fat concentration in patients with steatorrhea. Gastroenterology $1984 ; 87: 319-22$.

53. Pedersen N T, Halgreen $\mathrm{H}$, Woming H. Eswimarion of the 3-day Gaecal fat excretion and far concentation as a differential tesr of malabsorption and maldigestion. Scand J Gastroenterol $1987 ; 22: 91-6$.

54. Bai J C, Andrüsh A, Marelo G, Marrinez C, Vazquez H, Boerr L, Sambuelli A. Fecal fat concentration in the differential diagnosis of steatorthea. Am J Gastroenterol 1989; 84: 27-30.

55. Benini L, Caliari S, Bonfante F, Bardelli E, Castellani G, Sembenini C, Brentegani M T, Vancini I. Fecal fat concentration in the screening of steatorhea. Digestion 1992; 53: 94-100.

56. Sawedra J M, Brown K H. Nonabsorbable marker and single, random stool samples used for measuring intertinal absorption of macronutrients in infants and children. Am ] Clin Nutr $1991 ; 53: 790-4$

57. Zuckerman J L, Zymaris M C, Natelson B S, Natelson S. 1948, J Lab Clin Med:282-6.

58. Bekers O, Postma C, Lombarts A I P F. Determination of faecal far by near-infrated spectroscopy. Eur J Clin Chem Clin Biochem 1995; 33: 83-6.

59. Jeejebhoy KN, Ahmad S, Kozak C. Determination of fecal fats containing both medium and long chan miglycerides and fatty acids. Clin Biochem 1970:3: 157-63.

60. Khour $M \mathbb{R}$, Huang $\mathrm{G}$, Shiatu $\mathrm{Y} \mathbb{F}$. Sudan stan of fecal fat new insight into an ald rest. Gastroencerology $1989 ; 96: 421-7$.

61. Newcomer A D. Hofman A F, DiMagno E. P. Triolcin breath rest. A sentitive and specific test for fat malabsorption. Gastroenterology; $1979 ; 76: 6+13$.

62. Leus J, Van Biervliet $S$, Robberech $E$. Detection and follow up of exocrine pancrearic insufficiency in cystic fibrosis; a review. Eur J Pediar 2000; $159: 563-8$.

63. Peuchant $E$, Salles $C$, Jensen $R$. Value of apectroscopic fecalgram' in determining he crology of steatorhea. Clin Chem 1988; $34: 5-8$.

64. Stein J, Purschian B, Bienick U. Caspary W F, Lembke B. Near-infrared reflecance analysis: a new dimension in the investigation of malabsorprion syndromes. Fur l Gastroenterol Heparol $1994 ; 6: 889-94$

65. Neumeister $V$, Henker I, Kaltenborn G, Sprossig C, Jaross W. Simulaneous detcrminarion of fecal far, nitrogen, and water by near-infrared reflectance spectroscopy. I Pediat Gastroenterol Nutr 1997; 25: 388-93.

66. Picarelli A, Greco M, Dí Giovambatrista F, Ramazoti A, Cedrone C, Coraziari E, Torsoli A. Quantitave deremination of fecal fat, nitrogen and water by means of a spectrophotometric 
rednique near-infrared reflectance analysis (NIRA). Assesment of nts accuracy and reproducibiluty compared with chemical methods. Clin Chem Acra 1995; 234: 147-156.

67. Schneider MU, Demling L, Domschke S, Heptner G, Merkal Domschke W. NMR spectrometric stool fat analysis, a new technique for quankifying steatorthea and establiting the in. dication for enzyme replacenent in chronic pancrearitis. Hepatogastroenterology 1985; 32 : $210-15$.

68. Colombo C, Maravacca R, Ronchi M. Consalvo E, Amoretri M, Giunca A. The steatocrit: a simple method for monitoring fat malabsorption in parients with cystic fibrosis. I Pediatr Gastroenterol Nut 1987; 6: 926-30.

69. Guarino A, Tarallo L, Greco L, Cesaramo L, Guandalini S, Rubino A. Reference values of the steatocrit and its modifications in diarrheal diseases. I Pediarr Gastroenterol Nutr 1992; 14: 268.74 .

70. Walters M P, Kelleher J, Gibert J, Littlewood J M. Clinical moniconing of steatorhea in cysric fibrosis. Arch Dis Child 1990; 65:99-102.

71. Rawashdeh M O, Lloyd D R. Puntis I W L., Brown G A, Booth I W. Using the stearocric to derermine optmal fa content in modular feeds. Arch Dis Child 1992;67:608-12.

72. Tran M, Forget P, Van den Neucker A, Serik J, wan Kreel B, Kuigten R. The acid stearocrita a much improved method. J Pediarr Gastroenterol Nutr 1994; 19:299-303.

73. Bettinardi N, Colombo C. Corberta C. In vitro influence of different kinds of fats on resules and imprecision of classic and acid steationits. Clin Chem 1999; 45: 406-7.

74. Amann ST, Josephon SA, Toskes P P. Acid steatocrit: a simple, rapid gravimetric method to determine steatorrhea. Am J Gastroenterol 1997; 92: 2280-4.

75. Jonas A, Weiser S, Segal P, Karznelson D. Oral far loading test. Arch Dis Child 1979; 54 , $770-2$.

76. Robards M F. Changes in plasma nephelomeny after oral far loading in children with normat and abnormal small intestinal morphology. Arch Dis Child 1975; 50;631-36.

77. Tangney CC, Shekelle RB, Raynor W, Gale M, Betz EP. Intra- and interindividual variation in mensurements of beta-carotene, retinol, and rocopherols in dier and plasma. Am J Clin Nutr $1987 ; 45: 764-9$.

78. Heller FR, Vandenplas C, Desager JP, Harvengt $C$. The vitamin A far-loadind test in young normolipidemic subjects. Clin Chm Acta 1993; 219: 167-76.

79. Harper $G$ D. Wheler D C, Wicks A C. Butterat absorprion a valuable screening test in malabsorption. Postgrad Med J 1994:70: $23-16$.

80. Benini l. Scuro L A, Menini E, et al. Is the ${ }^{14}$ C-riolein breath test useful in the assessment of malabsorprion in dintal practice? Digestion $1984 ; 29: 91-7$.

81. Kalivinakis M. Verkade H J, Stellard F, Vander Wer M, Elzinga H, Vonk R J. The ${ }^{13} \mathrm{Cumixed}$ triglyceride breath rest in healthy adults: determinants of the ${ }^{13} \mathrm{CO}^{2}$ response. EurJ Clin Invest 1997; 27:4344442.

82. Perri F. Pastore M. Festa V. Clemente R. Quitadamo M, D'Arilia M R, Niro G, Paolucci P, Andriulli $A$. Intradoudenal lipase activicy in celiac disease assessed by means of ${ }^{13} \mathrm{C}$ mixed-riglyceride breath rest. J Pedian Gastroenterol Nutr 1998; 27:407-10.

83. Weaver I. T. Stable isorope breach test. Nutrition 1998; 14:826-9.

84. Murplyy M S, Eastham EJ, Nelson R, Aynsley-Green A. Non-invasive assessment of intraluminall lipolysis using a ${ }^{13} \mathrm{CO}^{2}$ brearh rest. Arch Dis Child 1990; 65:574-8. 


\section{Aim of the thesis}

The aim of this thesis was to evaluate the clinical usefulness of the acid steatocrir method, a non-invasive, simple and cheap merhod for determining faecal far in a single stool sample. If this method is accurate, clinicians would be able to diagnose and monitor steatorrhoea in an easier, cheaper and faster way, with less discomfort for patients, parents, nurses and laboratory personnel. For this purpose the following investigarions were performed:

- Comparison of the results obtained by the AS method with those obtained by the original method as described by Phuapradit, as well as with the results obtained by the titrimetric chemical method of Van de Kamer, in order to demonstrate whether or not the merhod can be improved by acidificarion of faecal samples - chapter 2 .

- Comparison of the results of the AS method with those obtained by the gold standard method for determining faecal fat concentration: the titrimetric method of Van de Kamer; and with results obtained by the near-infrared analysis (NIRA) - chapter 3.

- Comparison of the results of lipid, nitrogen, water and energy measurements from a single stool sample with those of three-day stool collections in order to demonstrate whether or not a single stool sample can yield similar information to the more laborious stool collection method-chapter 4 .

- Determination of age-related normal values of AS, because normal neonates and infants excrete larger amounts of faecal fat - chapter 5 .

- Comparison of the results of single sample AS determinations with the results obtained by the faecal fat balance for the clinical diagnosis of steatorrhoeachapter 6 .

Evaluation of the value of the AS method in screening for steatorrhoea in children-chapter 7. 



\section{CHAPTER 2}

\section{The Acid Steatocrit: \\ A Much Improved Method}

Tran M, Forger P. Van den Neucker A, Strik J, van Kreel B, Kuijuen R.

Depariments of Pediatrics and Clinical Cheminty.

Uninersity Hospital Maditnidx. Mastrids. The Nederlands.

I Peduar Gasmoenterol Nurr 1994; 19:299-303

\section{Abstract}

The steatocrit method has recently been introduced as a simple screening test for steatorrhea. As it seemed likely that separation of fecal homogenate by centrifugation into a lipid phase, a watery phase and a solid phase would be $\mathrm{pH}$-dependent, we evaluated the effect of fecal acidification on steatocrit results. We also compared classical and acid steatocrit result in healthy children and in patients with cystic fibrosis and studied the relarionship between two steatocrit methods and fecal fat content as measured by a reference chemical method. Steatocrit results increased with the degree of fecal acidification, and maximal results were obtained at the lowest fecal $\mathrm{pH}$ values. Means and SEM for classical and acid steatocrit values were $1.1 \pm 0.4 \%$ (classical) versus $3.8 \pm 1 \%$ (acid) in controls ( $\mathrm{n}=$ 6) and $5.4 \pm 1.9 \%$ (classical) versus $26.9 \pm 4.3 \%$ (acid) in cystic fibrosis patients $(\mathrm{n}=9)$. The correlations between fecal fat content measured chemically and sreatocrit results were $0.18(\mathrm{p}=0.35)$ and $0.81(\mathrm{p}<0.0001)$ for classical and acid steatocrit, respectively. We conclude that acidification of fecal homogenates leads to a marked improvement in the steatocrit method. 


\section{Introduction}

The diagnosis of fat malabsorption is still mainly based on the 72-hour faecal fat quantitation in which daily stool fat loss is evaluated by collecting stools for 3 days and determining stool fat content by chemical methods. The most widely used chemical method is the titrimetric method as described by Van de Kamer at al. in 1949 (1).

Work by Kouri et al. has suggested that the titrimetric method largely overestimares nurritional fecal far losses because it measures not only malabsorbed exogenous far but also endogenous fat of various origuns such as biliary lipids and lipids derived from the turnover of intestinal epithelial cells and gut bacteria (2).

Making use of the staining properties of purified lipids in an artificial matrix, Khouri et al. have suggested the far absorption coefficient in normal adults is much higher than usually beliewed (2). Although the microscopic evaluation of steatorthea by Soudan stain provides a satisfactory screening method for steatorrhea, it is at best semiquantitative.

The steatocrit is a simple rest for the evaluation of fat malabsorption (3-6). Although several authors have reported the method to be satisfactory for the evaluation of steatorrhea, some have reported the steatocrit to be quite unreliable (6).

As it has been shown that fecal acidification results in an enhanced sensitivity of the Sudan fecal staining method (2), we wondered whether the same modification could improve fat extraction by centrifugation as performed in the steatocrit determination.

Consequently, we evaluated the effects of stool sample acidification on steatocrit determinations and to compared results from previously reported methods with acid steatocrit results in healthy children and in children with cystic fibrosis. We also determined the correlation between steatocrit results and fecal fat concentrations as measured by the reference chemical method of Van de Kamer et al. (1) to evaluate which of the rwo steatocrit methods gave the best estimare of fecal fat content.

\section{Methods}

\section{Clasic steatocrit method}

Stool (at least $0.5 \mathrm{gr}$ ) was diluted (1/3) with deionized water and thouroughly homogenized in a $5 \mathrm{ml}$ Potter Elvehjem tissue homogenizer (Heidolph Elektro KG Kelheim, no. 170-1700/20-200) stamper, tissue grind pestle (size 20 from Kontes Scientific Glassware Instruments, no. 885451-0020). The homogenate 
was aspirated into a $75 \mu \mathrm{l}$ plain glass haematocrit tube. The capillary tube was subsequently centrifuged horizontally $(13,000 \mathrm{rpm}$ for $15 \mathrm{~min})$ in a standard haematocrit centrifuge.

After centrifugation, the upper (fat) and bottom (solid) layers were measured with a graduated magnifying lens. Steatocrit was calculated as FL/ $/ F L+S L)$, where FL is the fatty-layer length and SL is the solid-layer length.

\section{'Acid' steatocrit method}

The method used was exactly the same as the classic steatocrit method except that, before aspirating the homogenate in the capillary tube, perchloric acid in various concentrations ( $5 \mathrm{~N}$ for maximal acidification) was added to the homogenate in a volume equal to $1 / 5$ of the homogenate wolume. The resulting acid homogenate was mixed for 30 seconds with a standard Vortex mixer.

\section{Chemical Determination of Stool Fat Concentration}

The method of Van de Kamer et al. was used to determine stool fat content (1).

\section{Experimental Design}

\section{Effect of stool homogenate acidification on steatocrit results}

To evaluate the effect of stool acidification and thus stool pH on the length of the fat column obtained by centrifugation, several stool samples from patients with and without steatorthea were centrifuged after addition of perchloric acid solutions of various concentrations.

\section{Classic and acid steatocrit}

To compare classic and acid steatocrit results in children with and without steatorrhea, we measured fecal steatocrit by both methods in 6 control children (mean age: 5.8 years, range 3 to 12 years; five boys and one girl) and in 9 children with cystic fibrosis (mean age: 6.9 years; range 0.5 to 20 ; nine boys). The control children were parients with chronic aspecific respiratory disease withour gastrointestinal symptoms and with a normal sweat test. The cystic fibrosis patients all had abnormal sweat tests on several occasions and were being treated with pancreatic enzymes when steatocrit determinations were performed. As our purpose was to compare classical and acid stearocrit results in the same fecal samples, no attempt was made to quantify the fat content of the diet which was 'normal' in all patients.

\section{Correlation between steatocrit results and fecal fat content}

To further compare both steatocrit methods we looked at the relationship between results obtained by each method and fecal fat content results as measured by the method of Van de Kamer et al. (1). Steatocric measurements (classic and 
acid) and fecal fat content determinations (chemical method) were performed on 27 consecutive stool samples (from adults and children) sent to our laboratory for evaluation of malabsorption. No attempt was made to classify patients in disease categories as our only goal was to study the relationship between steatocrit results and fecal fat content independent of the presence of disease (clinical results will be published separately $\%$.

\section{Statistical methods}

The coefficient of variation of each steatocrit method was determined with duplicate results of each sample for both methods. Pearson correlation coefficient was used to evaluate the relationship between steatocrit results and chemically measured fecal fat content.

\section{Results}

Effect of stool homogrenate acidification on fat extraction

Several steatorheal stool samples were analysed after acidification with various concentrations of perchloric acid.

A typical finding is shown in figure 1; the upper fat column was seen to increase in length with the degree of homogenate acidification. A typical normal stool sample result (no steatorrhea) is shown in figure 2 . The acid steatocrit remained completely negative in normal samples.

\section{Classic and acid steatocrit}

Results of classic and acid steatocric in 6 control and 9 cystic fibrosis patients (figure 3) were as follows: Steatocrit means and SEM in control patients were $1.1 \pm$ 0.4 and $3.8 \pm 1 \%$ for classic and acid steatocrit, respectively. This difference was not statistically significant. Steatocrit means and SEM in cystic fibrosis patients were $5.4 \pm 1.9$ and $26.9 \pm 4.3 \%$ for classic and acid steatocrit, respectively. This difference is significant $(\mathrm{p}<0.01)$.

The precision of the methods was eval uated by comparing the variation coefficients; variation coefficients were 6.9 and $5.1 \%$ for the classic and acid steatocrit methods, respectively. 


\section{Cystic fibrosis sample}

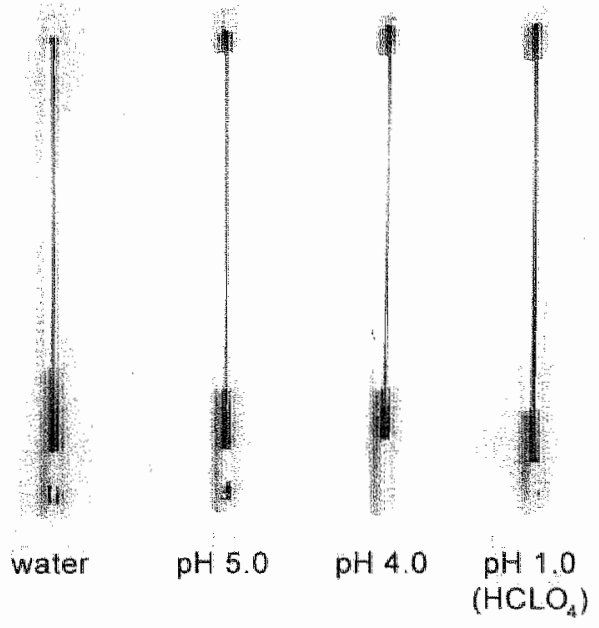

Figure 1. Effecr of acidification with various concentrations of perchloric acid on the fat column length (upper part of picture) of a stool sample from a patient with cystic fibrosis.

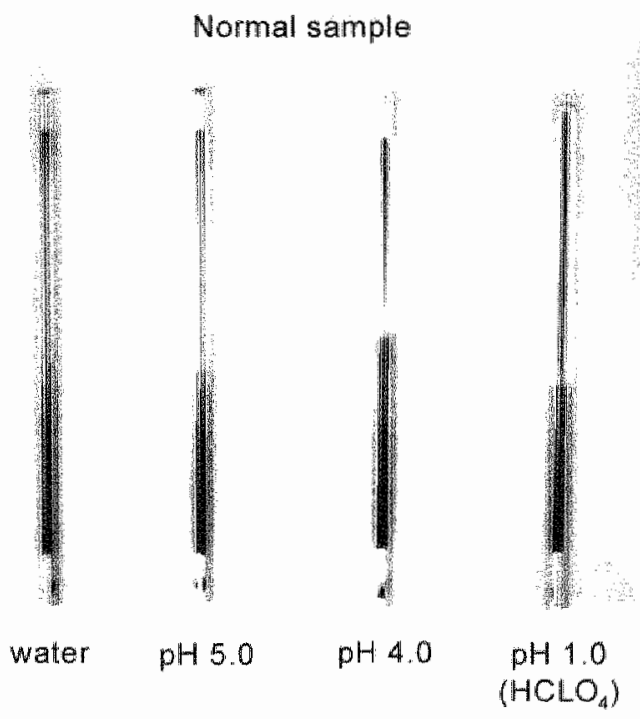

Figure 2. Effect of acidification with varions concentrations of perchloric acit on fat extraction fiom a normal stoot sample. Fat layer is absent at all pH valteses. 


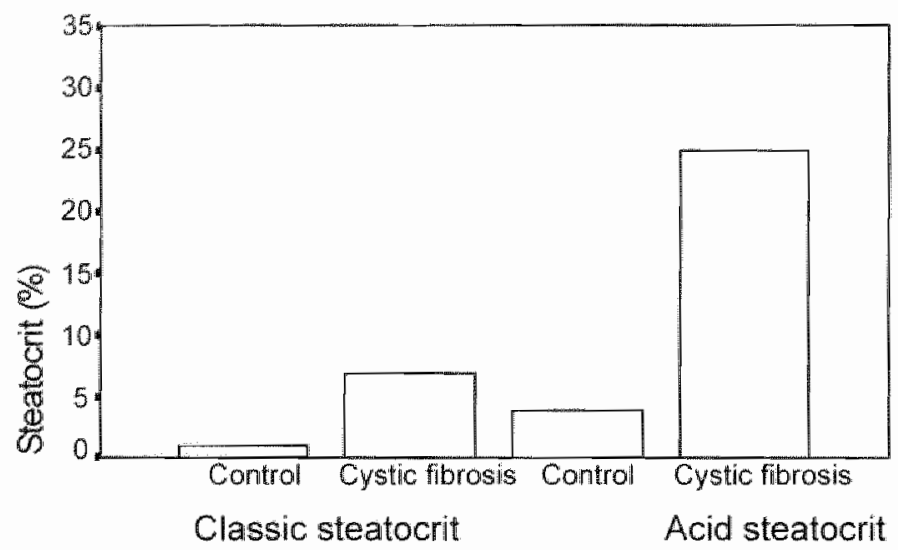

Figure 3. Classic and acid steatocrit results in six controls and nine parients with cysric fibrosis.

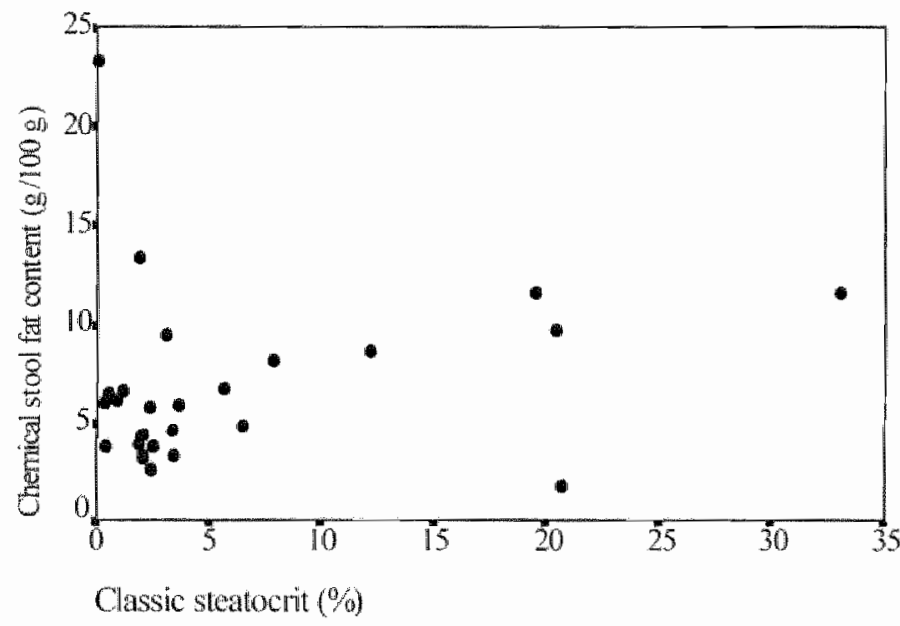

Figure 4. Relationship berween classic fecal steatocrit and feal fat contenc as measured by the method of van de Kamer et al. In 27 fecal samples $(r=0.18 ; p=0.35)$.

Correlation berween steatocrit results and fecal fat content

The relationship between classic fecal steatocrit and fecal fat content as measured by the reference method of Van de Kamer et al. (1) is shown in figure 4 . The correlation coefficient of 0.18 is statistically non-significant $(\mathrm{p}=0.35)$. The relationship between acid fecal steatocrit and fecal far content is shown in figure 5 . The correlation coefficient of 0.81 is highly significant $(\mathrm{p}<0.0001)$. 


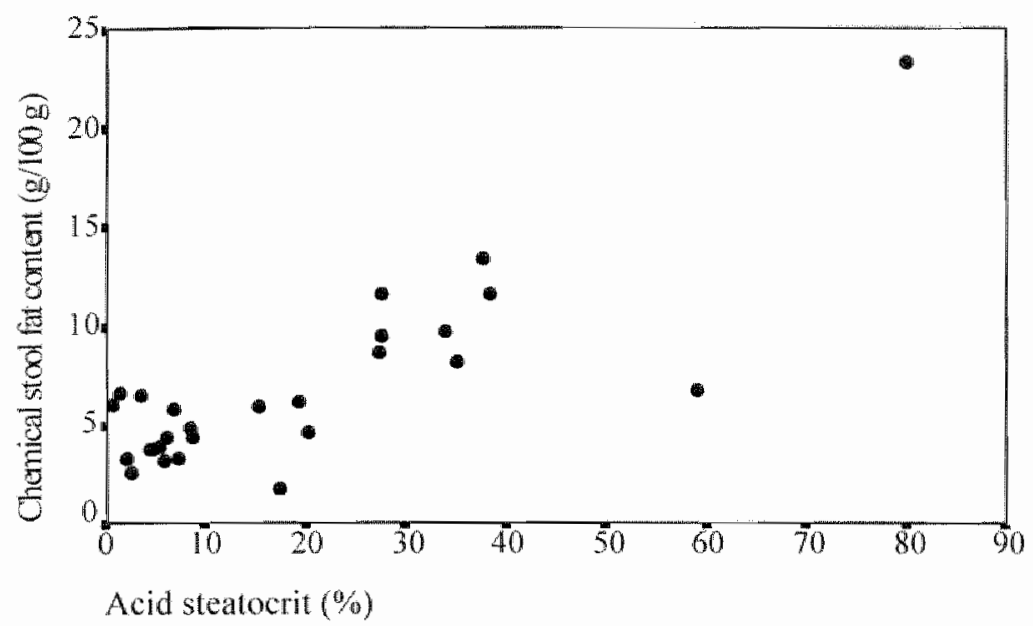

Figure 5. Relarionship between acid fecal steatocrit and far content as measured by the merhod of Van de Kamer er al. In 27 fecal samples ( $=0.81 ; p<0.0001$ ).

\section{Discussion}

Although several authors have reported the steatocrit method to be reliable for the screening of steatorrhea (3-5), Walters et al. reported the method ro be completely unreliable (6). Methodological inadequacies probably underlie these discrepancies. We have been using the 'classic' steatocrit in our deparment for a few years and have found completely negative results in some parients with proven steatorthea. We hypothesized that in some patients fat detection might be poor and that a possible solurion to the problem would be an improved merhod of liberating fat during the centrifugation step. It has been shown in al recent stu$\mathrm{d} y$ that fecal fat in patients with pancreatic insufficiency mainly consists of farty acids and that the fecal triglyceride content does not differ from that of normal controls (7).

Fecal fatty acid molecules exist in the form of soaps (8). Further, since the pKa of most fatty acids is lower (about 4.8) than fecal pH, most fatty acids in stool would be present as ionized species or soaps. We speculated that fecal acidification would result in the conversion of ionized farty acid species and soaps into the proconated species leading to easier separation into lipid and water phases during the centrifugation step of the steatocrit method.

Our resules show that the effect of stool homogenate acidification on the length of the upper fatty layer very nicely confirms our predicrions. Although we 
have not checked this point in detal, it can be expected that at the low $\mathrm{pH}$ values obtained after maximal acidification as performed in the present study, all farty acids will be present in the protonared form.

Further, acidification of fecal samples from parients without stearorrhea and with completely negative steatocric results did not result in the appearance of a fatry layer, probably indicating that the improved fat extraction is not a spurious artifactual finding but the result of better extraction of lost exogenous fat.

Khouri et al have suggested that ionized fatty acids are not readily stainable with Soudan stain, although staining does occur after acidification (2). By alkalinization with sodium hydroxide, the same authors showed that fatty acids lost their ability ro form fat droplets and to stain with Sudan red III (2). We suppose that similar mechanisms underlie the improvement of both the fat staining method and fat extraction by fecal acidification as shown in the present study.

A further advantage of acidification is that it enhances the visible boundaries between the various layers, resulting in improved accuracy in the reading of layers lengths. Improved fecal fat extraction by acidification should therefore result in higher diagnostic sensirivity of the steatocrit method.

Our results with classic steatocrit in control children and in children with cystic fibrosis are similar to results published by other authors (4); however, acidified steatocrit results in both control children and cystic fibrosis patients were much higher than those obtained by classic steatocrit. Ongoing work in our laboratory aims at establishing normal population values for acid steatocrit in infants and children.

To better interpret the differences found between the steatocrit methods, we compared steatocrit results with fecal fat concentrations measured by the most accepted reference method. Our findings show that only acid steatocrit results correlate very significantly with fecal fat content as measured by the Van de Kamer method. The litterature is quite varied on this point. Several studies have looked for a correlation berween steatocrit results and either the fat absorption coefficient or 3-day fecal fat excretion. A good correlation was reported by two studies $(4,9)$ while a total lack of correlation was reported by a third (6). As steatocrit is supposed to reflect fecal fat concentration we preferred to relate steatocrit results to fecal fat concentrations rather than daily excretion or fat absorption coefficients. To our knowledge only one study reporring results in a similar way found a significant rellationship between steatocrit results and fecal fat content (3). We think our finding of a lack of correlation between classic steatocrit and fecal fat content results can best be explained by the small number of observations or by the lack of homogeneiry in our patient material.

This lack of homogeneity was, however, purposely chosen as we were only inrerested in the correlation berween steatocrit results and fecal fat content. We think a posirive correlation between the rwo steatocrit methods and fecal fat con- 
tent could have been found but the acid steatocrit method would always better correlate with fecal fat content.

We conclude that acidification of fecal homogenates led to a much betrer fat extraction by centrifugation, increased sensitivity of the steatocrit method and better prediction of fecal fat content as measured by chemical methods.

\section{References}

1. Van de Kamer $\int H_{3}$ Huinink HTB, Weyers HA. Rapid method for determination of fat in feces. J Biol Chem 1949; 177:349-55.

2. Khouri MR, Huang G, Shiau YF. Sudan stain of fecal fat: new insight into an old test. Gastroenterology 1989; 96: $421-7$.

3. Phuapradit P, Narang A, Mendonca P, Harris DA, Baum JD. The steatocrit: as simple method for estimaring stool fat content in newborn infants. Arch Dis Child 1981; 56:725-7.

4. Colombo C, Majavacca R, Ronchi M, Consalvo E, Amoretti M, Giunta A. The steatocrit: at simple method for moniroring fat malabsorption in parients with cystic fibrosis.] Pediatr Gastroenterol Nutr 1987; 6: 926-30.

5. Iacono $G$, Canroccio $A$, Cavataio $F$ et al. Steatocrit test: normal range and physiological variation in infants. J Pediatr Gastroenterol Nurr 1990; 11:53-7.

6. Wallers MP, Kelleher J, Gilbert J, Littlewood JM. Clinical monitoring of steatorthea in cystic fibrosis.Arch Dis Child 1990; 65: 99-102.

7. Khouri MR, Huang G, Shiau YF. Fecal triglyceride excretion is not excessive in pancreatic insufficiency. Gastroenterology 1989; 96: 848-52.

8. Shiau YF, Popper DA, Reed M, Umstetter C, Capuzzi D, Levine GM.Intestinal triglycerides are derived from both endogenous and exogenous sources. Am J Physiol 1985; 248: G 164-9.

9. Guarino A. Tarallo L, Greco L, Cesarano L, Guandalini S, Rubino A. Reference values of the stearocrit and its modifications in diarrheal diseases. J Pediatr Gastroenterol Nutr 1992; 14 : $268-74$. 


\title{
CHAPTER 3
}

\section{Comparison of near infrared reflectance analysis of faecal fat, nitrogen and water with conventional methods, and faecal energy content.}

\author{
Anita Van den Neucker, Charles M.A. Bijleveld", Berr G. Wotthers" \\ Joost C.J.M. Swatneburg", Arnold D.M. Kester", Bernard van Kreel, Pierre-Philippe Forger'

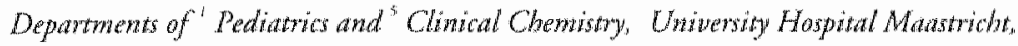 \\ Departments of "Pedatrics and "Cental Laboratary, Untwersity Hospital Grawingew. \\ Deparment of "Methodology and Statistics, Matstricht Universty. The Netherlands. \\ (submitred)
}

\begin{abstract}
Background: the Near-Infrared Analysis (NIRA) method for determining faecal fat, water and nitrogen is described as a new, easy and rapid method. Aim of the study: to evaluate the Near-Infrared Analysis method.

Methods: the results of faecal fat, water and nitrogen by both NIRA and by standard techniques were compared. Standard techniques consisted of Van de Kamer and Acid Steatocrit (AS), the Dumas and the vacuum drying methods for far, nitrogen and water respectively.

Resuls of fat methods were also compared with total faecal energy as obtained by bomb calorimeter.

Results: NIRA results correlated significantly $(\mathrm{p}<0.001)$ with standard methods for nitrogen $(r=0.79)$, fat $(r=0.84$ and $r=0.88$ for Van de Kamer and AS respectively) and water $(r=0.91)$. The limits of agreement for nitrogen and fat results were too wide for the merhods to be used interchangeably. The faecal fat resulrs correlated significantly $(\mathrm{p}<0.001)$ with faecal energy results.

Conclission: NIRA may be valuable for monitoring malabsorption but the diagnosric value remains to be determined.
\end{abstract}


Abbrewations: NIRA: near-infrared analysis, AS: acid steatocrit, w w: wet weight.

\section{Introduction}

Stool composition may give important information for the diagnosis and monitoring of malabsorption. Various laboratory methods are used for the determination of faecal fat, faecal nitrogen, faecal energy and faecal water. Most of these methods are both time consuming and unpleasant to perform.

Near-Infrared Reflectance Analysis (NIRA) of faecal material is a new and rapid method for the determinarion of faecal fat, nitrogen and water content $(1,2,3,4,5)$. Results obtained with new techniques should be compared with those of standard methods prior to introducing them as routine clinical methods.

The aim of the present study was to compare results of faecal fat, nitrogen and warer as obtained by the NIRA, with those obtained by accepted techniques as rourinely used in our laboratory: the titrimetric method of Van de Kamer (6), the acid steatocrit method (AS) (7) for the evaluation of faecal fat, the method of Dumas (Foss-Heraeus Macro- $N$ ) $(8,9)$ for the determination of faecal nitrogen, vacuum-drying for the evaluation of faecal water content and bomb calorimetry (10) for obtaining the total amount of faecal energy.

\section{Methods and material}

60 stool samples ( $11.0 \mathrm{~g}$ faeces), immediately frozen at $-18^{\circ} \mathrm{C}$ and taken from 11 different patients with known or suspected steatorrhoea were examined. All patients but one suffered from cystic fibrosis with pancreatic insufficiency and received enzyme subsritution therapy. Faecal fat was determined $(\mathrm{g} / 100 \mathrm{~g}$ faecal wet weight) by the NIRA (Fenir 8820-infrared-Analyser, Stimotron, Wendelstein, Germany) (1), by the titrimerric method of Van de Kamer (g/100 g faecal wet weight) (6) and by the Acid Steatocrit method (\%) (7).

Faecal nitrogen was determined by the NIRA $(\mathrm{g} / 100 \mathrm{~g}$ faecal wet weight) and by the method of Dumas (Foss Electric Benelux, Hoorn. The Netherlands) (mg/g faecal dry weight) (8).

Faecal water was determined by the NIRA (g/100 g faecal wet weight) and by weighing and vacuum-drying (Heraeus, Foss Electric Benelux, Hoorn, The Netherlands) (g/100 g faecal wet weight). 
NIRA determinations and determinations of faecal fat according to the ritrimetric method of Van de Kamer were performed in a separate laboratory and the investigators were blind for each others results.

The NIRA-apparatus was used with the calibration curve as delivered by the manufacturer.

Faecal energy ( $\mathrm{kJ} / \mathrm{g}$ faecal dry weight) was obtained using a bomb calorimeter (lka-calorimeter system C700T, Heitersheim, Germany) (10).

Results were calculated in the same units for comparison.

Energy was calculated from different components by multiplying the amount of protein and lipid by 16.7 and $37.7 \mathrm{~kJ} / \mathrm{g}$ respecrively (Arwater and Benedict) (11).

All results were managed using the SPSS statistical program. Correlations between the results obtained by the different methods were evaluated making use of the Spearman correlation coefficient and the limits of agreement obtained by the method of Bland and Altman were indicated whenever applicable (12).

\section{Results}

\section{Faecal nitrogen}

Mean results of faecal nitrogen determinations expressed in $\mathrm{g} / 100 \mathrm{~g}$ wet faecal weight for the Dumas and NIRA methods were: 1.18 (range: $0.73-1.70 ; \mathrm{SD}$ : 0.32 ) and 1.24 (range: $0.73-1.99 ; \mathrm{SD}: 0.29$ ) respectively.

The correlation coefficient between results of the nitrogen concentration as determined by the Dumas ( $\mathrm{x}$ ) and results obtained by the NIRA (y) expressed in $\mathrm{g}$ per $100 \mathrm{~g}$ wet faeces was $0.79(y=0.11+0.87 \mathrm{x}$; res. SD: 0.20$)$. The limits of agreement were $0.45 \mathrm{~g} / 100 \mathrm{~g}$ and $-0.35 \mathrm{~g} / 100 \mathrm{~g}$ faecal wet weight (fig 1.).

\section{Faecal water}

The faecal water content, measured with the vacutum drying method, reached a mean value of $72.57 \%$ (min.: $53 \%$; $\max : 88 \%$; $5 \mathrm{D}$ : $6.27 \%$ ), whereas the values obtained with the NIRA were (mean) 74.67\% (min.: 58\%; max.: 95\%; SD: $7.25 \%$ ).

The correlation coefficient between results of the faecal water content as determined by the vacuum-drying method $(y)$ and the NIRA ( $x)$ was $0.91(y=0.79 x+$ 12.8; res. SD: $2.59 \%$ ) and the limirs of agreement $+8.15 \%$ and $-3.65 \%$ (Fig. 2 ).

The correlation berween results of faecal water as determined by the vacuum-drying method $(y)$, taken as reference method, and faecal far $(x)$ determined respectively by the method of Van de Kamer, the AS and the NIRA, were: 
$r=-0.54(y=80.1-0.89 x ;$ res. SD: 5.35$)$,

$r=-0.70(y=80.6-0.28 x ;$ res. SD: 4.55$)$,

$r=-0.85(y=0.85-1.63 x$; res. $S D: 3.33)$ respecrively.

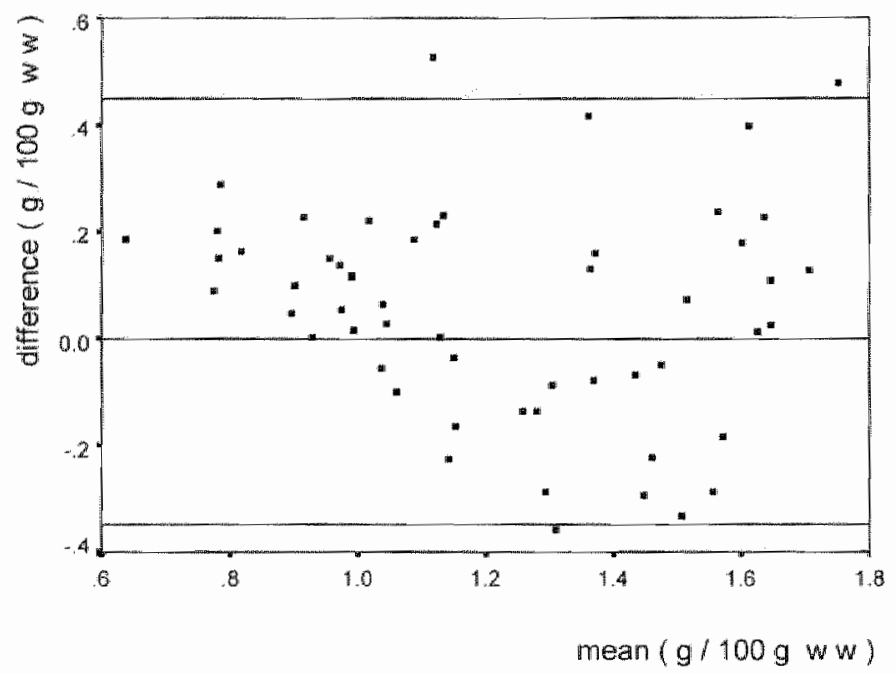

Figure 1. Limits of agreement berween the nitrogen results as determined by the method of Dumas and NIRA.

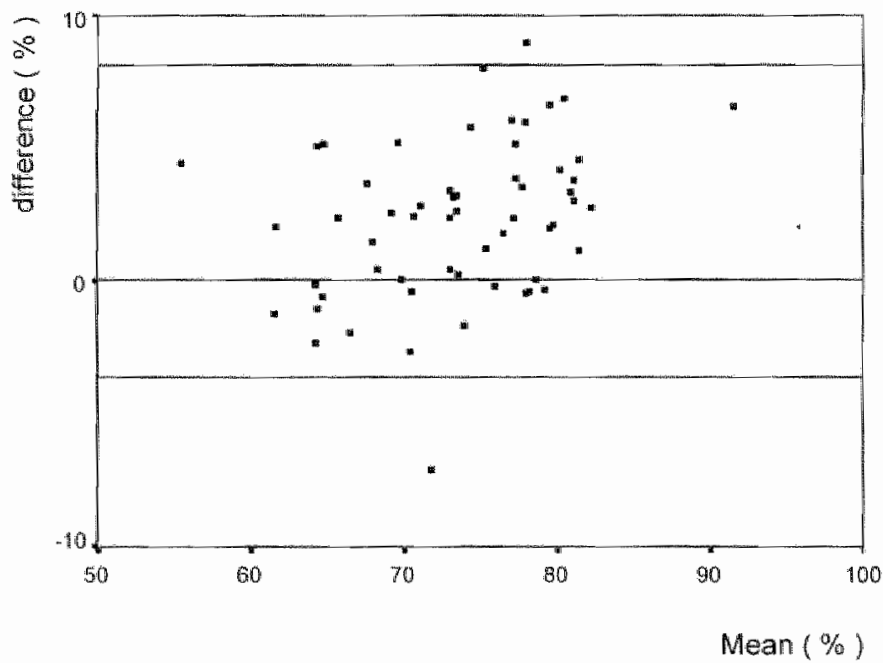

Figure 2. Limirs of agreement berween the water results as determinod by the vacuum drying method and the NIRA. 


\section{Faecal fat}

Mean value and SD for the AS results were $29.5 \pm 16 \%$. Mean results of the faecal fat determination according to the method of Van de Kamer and the NIRA were as follows: 8.88 and $8.05 \mathrm{~g} / 100 \mathrm{~g} \mathrm{w}$ w faeces with a standard deviation of 3.80 and $3.31 \mathrm{~g} / 100 \mathrm{~g} w$ faeces respectively.

Table 1. shows the regression analyses for results of the three faecal fat determination methods: AS, NIRA and Van de Kamer. The correlation coefficients for the three compared methods were almost equal $(95 \%$ confidence interval of $\rho$ for $\mathrm{n}=50$ and $\mathrm{r}=0.88$ is $0.78<p<0.92$ ).

Table 1. Results of regression analyses for results of faecal fat determination methods.

\begin{tabular}{llll}
\hline Method & $\begin{array}{l}\text { Correlation } \\
\text { coefficient }\end{array}$ & Equarion & Residual SD \\
Vd Kamer w AS & $r=0.81$ & $y=0.20 x+2.96$ & $2.24 \mathrm{~g} / 100 \mathrm{~g}$ \\
Vd Kamer w NIRA & $r=0.84$ & $y=0.97 x+0.93$ & $2.09 \mathrm{~g} / 100 \mathrm{~g}$ \\
NIRA w AS & $r=0.88$ & $y=0.18 x+2.67$ & $1.60 \mathrm{~g} / 100 \mathrm{~g}$ \\
\hline
\end{tabular}

As the results of the Van de Kamer method and the NIRA-method were expressed in the same units, the limits of agreement of these methods could be determined. These limits were between $+4.88 \mathrm{~g} / 100 \mathrm{~g} \mathrm{w}$ waeces and $-3.42 \mathrm{~g} / 100 \mathrm{~g} \mathrm{w} \mathrm{w}$ faeces (Fig 3).

\section{Faecal energy}

Results of energy content (mean and SD) as measured by bomb calorimetry and expressed in $\mathrm{kJ} / \mathrm{g}$ faecal dry weight were: $26.66 \pm 2.32$ and expressed in $\mathrm{kJ} / \mathrm{g} \mathrm{w} w$ facces: $7.38 \pm 2.11$.

Table 2 shows the correlation between results obtained by the faecal fat determination methods and faecal energy as obtained by bomb calorimetry.

Table 2. Corrdation berween resuls of Gecal lat and faecal energy.

\begin{tabular}{llll} 
Method & $\begin{array}{l}\text { Correlation } \\
\text { coefficient }\end{array}$ & Equation & Residual SD \\
\hline Energy ws AS & 0.78 & $y=0.11 x+4.28$ & 1.33 \\
Energy w wd Kamet & 0.66 & $y=0.38 x+4.15$ & 1.60 \\
Energy w NIRA & 0.91 & $y=0.59 x+2.68$ & 0.90
\end{tabular}




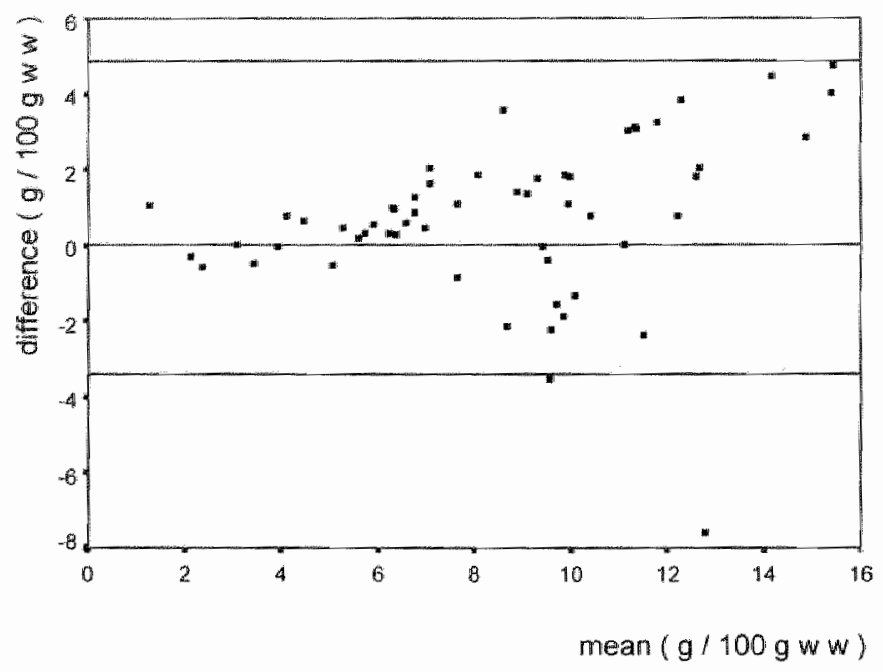

Figure 3. Limirs of agreement between the fat results as obtained by the method of Van de Kamer and the NIRA.

Faecal cnergy content attributable to protein (nitrogen $x 6.25$ ) and fat was calculated and expressed as percentage of faecal energy. The remaining energy was assumed to be attributable to carbohydrates. The energy was calculared from the amount of protein and lipid. The mean energy percentage for protein was $16.8 \%$. The mean energy percentage for fat varied between $44.1 \%$ and $42.6 \%$ of the total energy content depending on the method used for determining faecal $\mathrm{far}_{3}$, the titrimetric method of Van de Kamer and the NIRA respectively. The remaining energy amounted to $39.2 \%$ and $40.6 \%$ of the total energy. The mean faecal energy content was $7.38 \mathrm{~kJ} / \mathrm{g}$ w w faeces (SEM: $0.27 \mathrm{~kJ} / \mathrm{g}$ w w feces; SD: $2.11 \mathrm{~kJ} / \mathrm{g}$ w w faeces).

The correlation between faecal energy $(\mathrm{y})(\mathrm{kJ} / \mathrm{g}$ faecal wer weight) and faecal water $(\mathrm{x})(\%)$ as determined by the vacuum-drying method was $\mathrm{x}=-0.96(\mathrm{y}=$ $93.75-2.8 x$; res. SD: 1.88 ).

Our fesults (mean \pm SD) concerning faecal nitrogen, water, fat and energy are summarized in table 3.

Table 3. Resulrs of facal nitroger, water, fat and energy determinations (mean and SD).

\begin{tabular}{|c|c|c|c|c|c|c|c|c|}
\hline \multicolumn{2}{|c|}{$\begin{array}{c}\text { Nirrogen } \\
(\mathrm{g} / 100 \mathrm{~g} \mathrm{w} w)\end{array}$} & \multicolumn{2}{|c|}{$\begin{array}{c}\text { Water } \\
\text { (\%o })\end{array}$} & \multicolumn{2}{|c|}{$\begin{array}{c}\text { fat } \\
(\mathrm{mg} / 100 \mathrm{gw} w)\end{array}$} & \multicolumn{3}{|c|}{$\begin{array}{c}\text { Energy } \\
(\mathrm{k} / / \mathrm{g} w \mathrm{w})\end{array}$} \\
\hline Dumas & NIRA & $\begin{array}{l}\text { Vacuum } \\
\text { drying }\end{array}$ & NIRA & Vd Kamer & NIRA & Towal & Fat $(\%)$ & Protein (\%) \\
\hline 1.18 & 1.24 & 72.57 & 7667 & 8.88 & 8.05 & 7.38 & $44.1 / 42.6$ & 16.8 \\
\hline 0.32 & 0.29 & 6.27 & 7.25 & 380 & 3.31 & 2.11 & - & . \\
\hline
\end{tabular}




\section{Discussion}

We investigated 60 different samples from 11 different patients, assuming that these samples were all independent. Ideally, these samples should have been obtained from 60 different parients, especially when considering the limits of agreement. To assess the influence of using 60 samples from 11 patients, we applied a random effects model (DerSimonian and Laird, 1986) (13) to obtain separate values for the within-patient standard deviation and for the berween-patient standard deviation. The limits of agreement calculated from the resultant total standard deviation were only slightly different from those reported; for the comparison of nitrogen concentration obtained by the method of Dumas and the NIRA on dry faeces the limits would be -12.85 and $16.06 \mathrm{mg} / \mathrm{g}$ instead of -12.81 and $16.55 \mathrm{mg} / \mathrm{g}$. For comparing results of fat determinations according to the method of Van de Kamer and the NIRA, the limits would be -3.66 and 4.88 $\mathrm{g} / 100 \mathrm{~g} \mathrm{w}$ w faeces, instead of -3.42 and $4.88 \mathrm{~g} / 100 \mathrm{~g} \mathrm{w}$ w faeces. As these differences were very small, our results were further treated as if they came from 60 independent samples.

The near-infrared spectrometry technique on faecal material is shown to be reproducible, accurate and rapid for the determination of faecal fat, nitrogen, and water as previously reported (3). However, some difficulties have been reported concerning the calibration and the composition of the faecal material $(4,5,15)$. Our NIRA instrument was previously calibrated by the manufacturer by making use of measurements obtained by the method of Van de Kamer for the determination of faecal fat and the Kjeldahl method for the determination of faecal nitrogen, all performed in the same laboratory.

In the present study NIRA-determinations and fat determinations according to the method of Van de Kamer were performed in a different laboratory than nitrogen determinations according to the Dumas method, water determination by vacuum drying, $A S$ and calorimetry. And we correlated the results obtained by the NIRA with those obtained by our routinely used laboratory methods, which were not all the same as those used for calibration of the NIRA apparatus.

Faecal samples were used for NIRA-determinations as delivered by the patients without thorough homogenization, as recommended by the instructions of the manufacturer.

Faecal fat results were correlated with the AS results, since this method has been proven to be suitable for the evaluation of faecal fat $(7,14)$.

The amount of nitrogen in the stools was determined by the NIRA method wirh the calibration by the Kjeldahl method. The Kjeldahl method is considered the standard method for nitrogen determination, but we used the combustion 
method of Dumas for the nitrogen determination. This method is more suitable for handling a greater amount of samples ar once and has proven to be of equal or even superior (as it recovers more nitrogen from the material) value for the determination of nitrogen in biological material $(8,9)$.

The correlation coefficients berween results obtained by the NIRA and those obtained by the reference methods for fat, nitrogen and water were lower than those reported by other authors $(1,2,3,4,5)$ but still highly significant. Regarding the limits of agreement as calculared from our results we can conclude that, except for the water content the various methods can not be used interchangeably. We think that there are several explanations for these findings. First we compared NIRA results with results obrained by the methods currently used in our laboratory which were different from the methods used to calibrate the NIRA-apparatus. Secondly, our calibration of the analyser may have been insufficient, as different authors reported the difficulty of calibration as a problem associated with the spectrometric technique $(2,4,5,15)$ and lastly the homogenization of the samples. Our samples were unhomogenized, as recommended by the manufacturers instructions, but different authors indicated this to be a problem due to inhomogeneous excretion and (consequently) distriburion of fat/nitrogen in the faeces. Moreover, light reflection is influenced by inhomogeneous composition of the sample and particularly by the water content. Betkers et al (4) report that stools obtained from patients with diarrhea, when the water content exceeds $75 \%$, are unsuitable for spectrometric analyses. As the mean water content value of our samples almost reached this value, a great part of our samples would accordingly not be suitable for spectrometry. All our samples except one were taken from cystic fibrosis patients with exocrine pancreas insufficiency receiving enzyme substitution therapy where monitoring of stool composition could be clinically usefull.

Our results for water and energy are comparable with the results expressed per gram stool reported by Murphy er al. (16) for a group of patients with cysric fibrosis in whom stool lipid was reported to accoun for $41 \%$ of stool energy while we found $44.1 \%$ or $42.6 \%$ depending on the method used to determine faecal fat. The energy content per gram wet weight has been reported to be $8 \mathrm{~kJ} / \mathrm{g}$ wet weight while we measured a mean of $7.38 \mathrm{~kJ} / \mathrm{g}$ wet weight. Expressed in $\mathrm{kJ} / \mathrm{g}$ faecal dry weight our mean result amount to $26.6 \mathrm{~kJ} / \mathrm{g}$ while the reported mean result amounted $27.0 \mathrm{~kJ} / \mathrm{g}$ faecal dry weight. Although reporred results concerning energy were measured on 3 days stool collection and our results concern 'single stool" specimens, both were quite similar suggesting that single stool analysis can give useful clinical information in these patients with exocrine pancrearic insufficiency. From our own study we know that there is a significant correlation between the AS results from a single stool sample and results of a three days faecal fat 
collection as derermined by the method of Van de Kamer (14). Comparison with other components such as nitrogen and lipids is not possible as results in the literature are expressed in amounts per day, and not as a concentration.

\section{Conclusion}

In conclusion, our results show that NIRA results as obtained following the manufacturers instructions are not so accurate for the evaluation of far, nitrogen and water in faecal material and that the results cannot be used interchangeably with the currently used methods. When taking the shortcomings into account this method might be valuable for the monitoring of malabsorption but, as our limits of agreement for fat and nitrogen were large, the diagnostic value of the method remains uncertain. Further experience with the NIRA method is needed before deciding whether or not NIRA can replace the presently used routine methods.

Comparison of our results with results of the literature suggests that measurements performed on stool collections and on single stool samples give rather similar information on stool composition.

\section{References}

1. Benini L, Caliari S, Gudi GC, Vaona B, Talamini G, Vantini I, Scuro LA. Near infrared spec. trometry for faecal fat measurement: comparison with conwentional gravimetric and ticrimetric methods. Gur 1989:30:13441-7.

2. Stein I, Purschian B, Bieniek U, Caspary WF, Lembcke B. Near-infared reflectance analyois: at new dimension in the investigation of malabsorpcion syndromes. Eur I Gastro Heparol 1994;6:889-94.

3. Picarelli A, Greco M, Giovambattista F", Ramazzotri A, Cedrone C, Comaziari Es, "Torsoli A Quantitative determinarion of faceal far, nitrogen and water by means of spectrophotometric rechnique: near infrared reflectance analysis (NIRA). Assesment of its accuracy and reproducibiliry compared with chemical methods. Clin Chim Acra 1995:234:147-56.

4. Bekers O, Postma C, Lombarts AJPF. Determination of faceal fat by near-infrared spectroscopy. Eur J Chem Clin Biochem 1995;33:83-6.

5. Bekers O, Postma C, Fischer JC, Fanck PFH, Lombarts JPF. Faecal nitrogen deremination by near-infrared specrroscopy. Eur J Clin Chem Clin Biochem $1996,34: 561-3$.

6. Van de Kamer JH, Huinink HTB. Wejers HA. Rapid method for determination of far in facces. J Biol hem 1949;177:349-55.

7. Tran M, Forget P. Van den Neucker A, Strik J, van Kreel B, Kuigten R. The acid steatocrit: a much improved method. J Pediat Gastroenterol Nutr 1994:19:299-303.

8. Wilson PR. A new instrument concept for nitrogen/protein analysis. A challenge to the Kjeldahl method. Aspects of Applied Biology 25, Cereal Quality II 1990;443-6. 
9. Smith ID. Evaluation of the Foss-Heraeus Macro $\mathbb{N}$ for the determination of nirrogen in a wide range of foodsuffs, ingredienes and biological materials and comparison with the Kjel foss. Analypical proceedings $1991,28: 320-4$.

10. Miller DS, Payme PR. A ballistic bomb calormeter. Br J Nutr 1959;13:501-8.

11. Atwater WO, Benedict FG. Experiments on the metabolism of matter and energy in the human body. in: Bull Of Exp St Washington, D.C.U.S. Dept Agr 1903:136.

12. Bland JM, Atman DG. Starisrical methods for assessing agreement berween wo methods of clinical measurement Lancet 1986;8:307-10.

13. DerSmonian R. Laird N. Meta-analysis in clinical trials. Control Chin Trials 1986\%:177-88.

14. Wan den Neucker A, Pestel N, Tran TMD, Forget P-Ph, Veeze HI, Bouquer J, Sinaasappel M. Clinical use of acid steatocric. Acta Padiatr 1.997;86-466-9.

15. Grimble GK. Near-infrared refectance analysis as an investigative tool in gastroencerology. Eur J Gastroen Hepat 1994;6:885-8.

16. Murphy JL, Wootton SA, Bond SA. Jackson AA. Energy content of stools in normal healthy controls and parients with cystic fibrosis. Arch Dis Child 1991;66:495-500. 


\title{
CHAPTER 4
}

\section{Lipid, nitrogen, water and energy content of a single stool sample in healthy children and children with cystic fibrosis.}

\author{
Anita Maria Van den Neucker" MD, Pierre-Philippe Forger", \\ PhD, Bernard wan Kreel ${ }^{2}$ PhD. \\ 'Department of Pediatricr and' Deparment of Clinical Chewrisy \\ Uninersity Hospital Madstrich, The Netherlands. \\ (submitted)
}

\begin{abstract}
Objective: evaluate the usefulness of "single stool sample" analysis in the investigation of steatorrhoea.

Methods: we examined 57 srool samples of cystic fibrosis (CF) parients while on pancreatic enzyme therapy and 29 stool samples of healthy children.

We compared results of fat, nitrogen, water and energy content. Fat was determined by the method of Van de Kamer and the Acid steatocric (AS) method, water by vacuum drying, nitrogen by the Dumas method and energy was obtained using a bomb calorimerer.

Results: results (median, $10^{\mathrm{ht}}$ and $90^{\mathrm{th}}$ percentile) of fat were: 8.90 (4.68 $13.90)$ and $4.75(2.27-6.52) \mathrm{g} / 100 \mathrm{~g} w \mathrm{w}$ stool by the method of Van de Kamer and $28.6(5.5-49.8)$ and $7.2(3.0-15.0) \%$ by the AS method; energy results were: $742.96(525.59-997.24)$ and $549.32(451.48-7 \rrbracket 0.72) \mathrm{kJ} / 100 \mathrm{gww}$ stool all for CF patients and healthy controls respectively ( $p \leq 0.0001$ for both fat and energy).

The Mann-Witney U-rest was used for comparing means.

Conclusions: results of single stool sample water and nitrogen were similar in borh groups. Results were comparable to those reported from samples taken from stool collections as far as fat and energy concentrations are concerned and yield clinically usefull information.
\end{abstract}




\section{Introduction}

Most investigators and clinicians still make use of the 72-hour fecal collections for determining fecal losses of far, water, nitrogen and energy for clinical investigations $(1,2)$ and for monitoring patients with pancreatic insufficiency. However, different attempts have been made in order to develop alternative rapid and simple techniques $(3,4)$. In pediatrics, stool collections are mostly used for the monitoring of steatorrhoea in patients with cystic fibrosis. It is most often assumed that "single stool" analysis does not give useful diagnostic information in these patients.

The present study was designed in order to compare results of fat, nitrogen, water and energy of single stool samples in cystic fibrosis patients and in normal. children in order to establish wherher or not a single stool sample analysis can yield useful diagnostic information.

\section{Methods and material}

57 Stool samples of cystic fibrosis patients receiving enzyme substitution therapy, aged between 1.5 years and 11.6 years (mean: 7 years) and 29 samples of normal children, aged between 0.6 year and 16 years (mean: 7.6 years) were collected and immediately stored at $-18^{\circ} \mathrm{C}$.

Fecal fat was determined by both the tirrimetric method of Van de Kamer (5), expressed in $\mathrm{g} / 100 \mathrm{~g}$ fecal wer weight ( $\mathrm{w}$ w) , and the Acid Steatocrit (AS) method (3), expressed in \%. Fecal water was determined by weighing and vacuum drying (apparatus: Heraeus, Foss Electric Benelux, Hoorn, The Netherlands) and expressed in $\%$.

Fecal nitrogen was derermined by the method of Dumas (6) (Foss Electric, Hoorn, The Netherlands) and expressed in $\mathrm{g} / 100 \mathrm{~g}$ fecal wet weight. Fecal energy, expressed in $\mathrm{kJ} / 100 \mathrm{~g}$ fecal wet weight, was obtained using a bomb calorimeter (Ika-calorimeter system C700, Heitersheim, Germany) (7).

Results were managed using the SPSS statistical program. The Mann-Whitney $U$-test was used for comparing means. 


\section{Results}

Results are shown in table 1.

Table 1. Comparison of median, $10^{\text {th }}$ and $90^{\text {th }}$ percentile and p-values for fecal far, nirrogen, water and energy of single srool samples from healchy children and cysric fibrosis patients.

\begin{tabular}{|c|c|c|c|c|c|c|}
\hline Method & Groups & $n$ & Median & $\mathrm{P} 10$ & $\mathrm{P} 90$ & $p$-value \\
\hline Van de Kamer & normal & 28 & 4.75 & 2.27 & 6.52 & $<0.0001$ \\
\hline (g/ $100 \mathrm{~g} w$ & $\mathrm{CF}$ & 55 & 8.90 & 4.68 & 13.90 & \\
\hline AS & normal & 28 & 7.2 & 3.0 & 15.0 & $<0.0001$ \\
\hline$(\%)$ & $\mathrm{CF}$ & 57 & 28.6 & 5.5 & 49.8 & \\
\hline Nirrogen & normal & 27 & 1.322 & 1.078 & 1.871 & $=0.037$ \\
\hline$(\mathrm{g} / 100 \mathrm{~g} w \mathrm{w})$ & $\mathrm{CF}$ & 55 & 1.150 & 0.736 & 1.629 & \\
\hline Water & normal & 27 & 73.9 & 67.9 & 78.6 & $=0.650$ \\
\hline$(\%)$ & $\mathrm{CF}$ & 58 & 73.2 & 64.2 & 79.3 & \\
\hline Energy & normal & 27 & 549.31 & 451.475 & 710.72 & $<0.0001$ \\
\hline$(\mathrm{kJ} / 100 \mathrm{gw} \mathrm{w})$ & $\mathrm{CF}$ & 57 & 742.96 & 525.59 & 997.24 & \\
\hline
\end{tabular}

Median, $10^{\text {th }}$ and $90^{\text {th }}$ percentile for fecal fat as determined by the merhod of Van de Kamer and expressed in $\mathrm{g} / 100 \mathrm{~g} w \mathrm{w}$ stool were $8.90(4.68-13.90)$ and $4.75(2.27-6.52)$ for $\mathrm{CF}$ parients and normal children respecrively (fig 1). This difference is significant $(\mathrm{p}<0.0001)$.

Median, $10^{\text {th }}$ and $90^{\text {th }}$ percentile of Acid Steatocrit results were $28.6 \%(5.5 \%$ $49.8 \%)$ for CF patients and $7.2 \%(3.0 \%-15.0 \%)$ for healthy children. This difference is highly significant $(\mathrm{p}<0.0001)$ (fig. 2 ). 


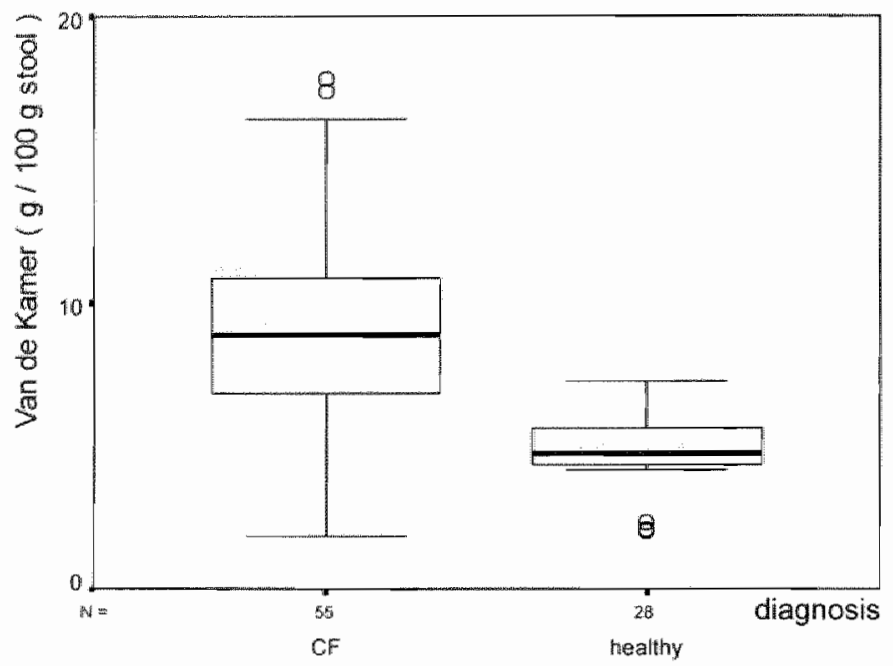

Figure 1. Boxplot of fecal far results as measured by the method of Van de Kamer.

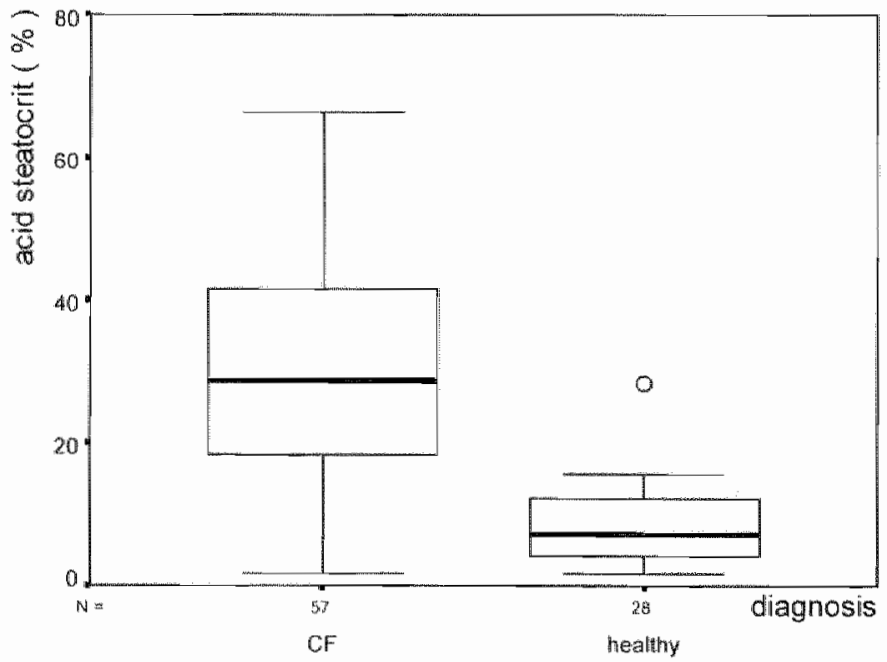

Figure 2. Boxploc of fecal fac results as measured by the AS method. 


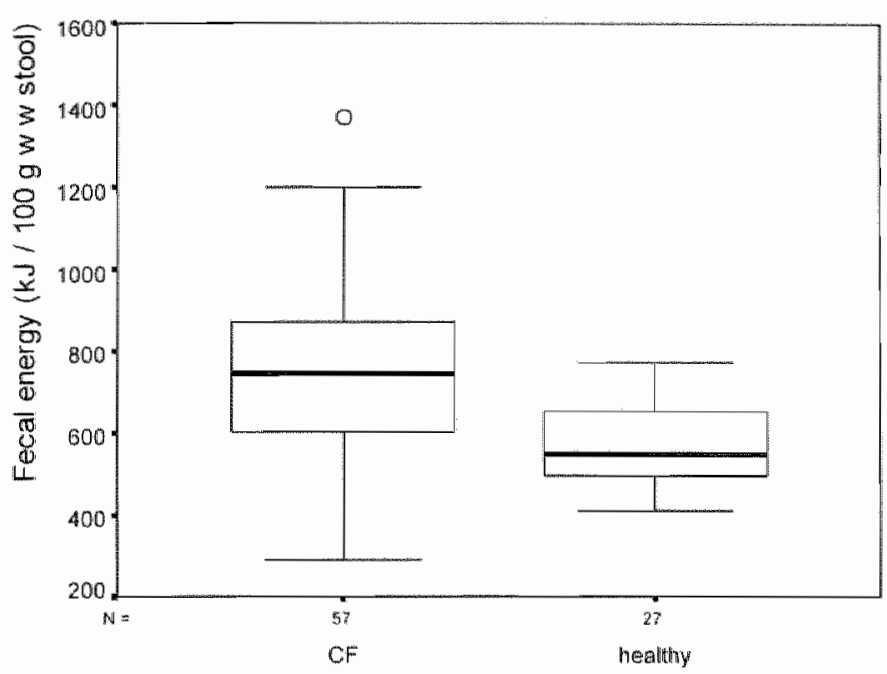

Figure 3. Boxplot of fecal energy results as measured by bomb calorimerer.

Single stool sample energy results (median; $10^{\text {th }}$ and $90^{\text {th }}$ percentile) expressed in $\mathrm{kJ} / 100 \mathrm{~g} \mathrm{w}$ w stool were: $742.96(525.59-997.24)$ for CF patients and: 549.32 (451.48-710.72) for normal children (fig 3). The differences found were significant $(\mathrm{p}<0.0001)$.

Median, $10^{\text {th }}$ and $90^{\text {th }}$ percentile of nitrogen determinations were $1.150 \mathrm{~g} / 100 \mathrm{~g} \mathrm{w}$ $\mathrm{w}(0.736 \mathrm{~g}-1.629 \mathrm{~g} / 100 \mathrm{~g})$ for CF children and $1.322 \mathrm{~g} / 100 \mathrm{~g} \mathrm{w} \mathrm{w}(1.078 \mathrm{~g}-$ $1.871 \mathrm{~g} / 100 \mathrm{~g})$ for healthy children $(p=0.037)$.

Median, $10^{\mathrm{h}}$ and $90^{\text {th }}$ percentile of fecal water contents were: $73.2 \%(64.2 \%$ $79.3 \%)$ for $C F$ patients and $73.9 \%(67.9 \%-78.6 \%)$ for healthy children $(\mathrm{p}=0.650)$.

The correlation coeficient between fecal fat results by the method of Van de Kamer and by the AS method was $0.80(y=3.35+0.66 x ; S E E=2.19 ; p \leq 0.0001)$ for CF patients and $0.14(y=4.60+0.45 x ; S E E=1.28 ; p=0.481)$ for healthy children.

The correlation coefficient between fecal energy results and fecal fat results by the method of Van de Kamer was $0.62(y=42.77+3.7 x ; S E E=16.2 ; p \leq 0.0001)$ and $0.48(y=38.78+3.7 x ; S E E=8.9 ; p=0.011)$ for CF parients and normal children respectively.

The correlation coefficient between fecal energy results and the AS results was: $0.77(y=44.03+1.05 x ; \mathrm{SEE}=13.4 ; \mathrm{p} \leq 0.0001)$ for CF patients and $0.25(y=$ $53.10+4.33 x ; \mathrm{SEE}=9.79 ; \mathrm{p}=0.214$ ) for healthy controls. 
The correlarion coefficient between fecal nitrogen and fecal energy results was $0.59(y=0.483+9.264 \mathrm{E}-04 \mathrm{x} ; \mathrm{SEE}=0.268 ; \mathrm{p} \leq 0.001)$ for $\mathrm{CF}$ patients and 0.77 $(y=0.197+2.065 E-03 x ; S E E=0.174 ; \mathrm{p} \leq 0.0001)$ for healthy children.

\section{Discussion}

This study shows that single stool sample results of fecal fat determinations (method of Van de Kamer and. AS) and fecal energy in cystic fibrosis children are significantly different from those obtained in healthy control children. Fecal fat and fecal energy results are, as expected, significantly higher in CF patients when compared to healthy controls. There is a good correlation between fecal fat results determined by the method of Van de Kamer and by the AS method. This correlation coefficient concerning the whole group is comparable to our previously reported data, where we correlated AS results with fecal fat as measured by the titrimetric method of Van de Kamer on a single stool sample taken from a homogenized 72 hours stool collection (8).

The poorer correlation between results of the AS determination and the Van de Kamer method in healthy controls can probably be explained by the small range of values obtained in healthy controls.

As reported by Murphy et al., fecal energy percentage atuributable to the colonic bacterial flora is comparable in healthy children and CF patients while the daily bacrerial mass is three times greater in CF parients than in healthy controls (9). We can consequently expect that fecal fat in CF patients contributes most to fecal energy as demonstrated by the good correlation that we obtained between fecal fat and fecal energy.

The stool energy concentration of CF patients is significantly higher than that of healthy controls. Our results concerning stool energy and fat content are comparable ro those reported by Murphy et al. (9) and Thomson et al. (1.0) for 72 houms stool collectrions.

Concerning feal nitrogen, results show slightly lower values in CF patients when compared to healthy controls. Previous studies have shown the daily loss of fecal nitrogen to be wwice as high in CF patients when compared to healthy children, with a similar proportional increase in daily stool weight (9). In this situation similar nitrogen concentrations should be expected.

Our findings show slightly higher nitrogen concentration in healthy children when compared to CF parients.

In agreement with licerature data (9), fecal water concentration of CF patients and healthy children was similar. 
Our results show that single stool sample fecal lipid and energy concentrations were significantly higher in CF patients when compared to healthy controls, while no clear differences were found for nitrogen and water concentrations. This is in agreement with literature data (9). Different studies indicate steatorrhoea to be mainly responsible for the loss of energy in exocrine pancreatic insufficiency. This information can be obtained from a single stool sample. Concerning the nitrogen loss, the daily loss rises with the daily srool weight, which consequently has to be measured. The latter informarion is not obtainable from a single stool sample analysis.

\section{Conclusion}

Our study shows that in CF patients the fecal lipid, water, nitrogen and energy concentrations obtained from single stool samples are similar to those reported from three day stool collections. Increased fat and energy losses are clearly apparent from single stool sample results, where as nitrogen losses are not. For the latter evaluation and for detailed quantitative evaluation of fecal losses the fecal balance technique remains necessary. For the frequent monitoring of fecal fat and energy, single stool sample analysis can be useful.

\section{References}

1. Lowdon J, Goodchild MC, Reyley HC, Doull HM. Mairtenance of growd in cystic fabrosis despite reduction in pancreatic anzyme supplementation. Arch Dis Child 1998; 78:377.78.

2. Regele $S$, Henker J, Munch R, BarbierY, Stern M. Indirect parameters of pancheatic funchion in cystic fibrosis (CF) during a controlled double- bland trial of pancraric supplementation. I Pediaur Gastroenterol Nutr 1996; 22:68-72.

3. Tran M, Forget P, Van den Nencker A, Strik I, Van Kreel B, Kuijten R. The acid statocrit: a much improved method. J Pediar Gastroenterol Nur 1994; 19:299-303.

4. Benini L, Caharis, Gudi GC, Vaona B, Talamini G, Vanmi I, Scuro LA. Nearinfrared specromery for faecal fat measuremenc: comparison with conventional gavimetric and rimetric methods. Gur 1989; $30: 13447$.

5. Van de Kamer $] \mathrm{H}$, Hennink HTB, Weijers HA. Rapid method for deternination of fat in feces. I Biol Chem 1949: 177:349-55.

6. Wilson PR. A new instrument concept for nitrogen? protein analysis. A challenge to the Katdahl merhod. Aspects of Applied Biology 25, Cereal Quality II 1990; 443-6.

7. Miller DS, Payne PR. A ballistic bonb calorimeter. Br I Nutr 1995; 3:501-8.

8. Van den Neucker A, PestelN, Tran TMD, Forger P-Ph, Veeze HJ, Bouquet ], Sinaasappel M. Clinical use of Acid Steatocrit. Acra Pediatr 1997; 86:466-9. 
9. Murphy JL, Wootion SA, Bond SA, Jackson AA. Energy content of stools in normal healthy controls and parients with cystic fibrosis. Arch Dis Child 1991; 66: 495-500.

10. Thomson M, Clague A, Cleghorn G] and Shepherd. RW. Compararive in vitro and in vivo studies of enteric-coared pancrelipase preparetions for pancreatic insufficiency. I Pediarr $\mathrm{G}$ àstroenterol Nurr 1993; 17:407-13. 


\title{
CHAPTER 5
}

\section{Acid steatocrit during infancy.}

A Van den Neucker, P Forget, I A Veneberg, B IS Schutten, B wan Kreel

Department of Pediatrics and Chemistyy,

University Hospital, Madustich, The Netherlands

Acta Paediatr 1996; 85: 1153-5.

\begin{abstract}
The fecal acid steatocrit is an improved steatocrit method for the evaluation of fecal fat. The present study was set up in order to establish reference values during the first year of life.

Fecal acid steatocrit values were determined in 58 healthy full term and in 16 healthy prematurely born infants.

Very high acid steatocrit results $(>60 \%)$ were found in all premature and many formula-fed term infants during the first six months of age, with thereafter values $<10 \%$. In 40- to 120-day-old infants acid steatocrit results of human milk-fed infants were significandy lower than those of formula-Fed infants $(p<0.01)$.

High acid steatocrit results after the age of six months are indicative of fat malabsorption while, before this age high values can be due to physiological stearorrhea. The acid steatocrit should be useful for the evaluation of milkfat absorption in infants.
\end{abstract}




\section{Introduction}

Adequate food intake and absorption is of grear importance for the development of children especially during the first year of life. Fat malabsorption has to be considered as an important cause of poor growth in infancy and childhood, in both rerm and premature babies. The 72 -hours ballance study is considered to be the gold standard for the diagnosis of far malabsorption in children and adults (1). This test is not only unpleasant and time consuming, but even very difficult to perform in infants with stools often loose and watery.

In 1981 Phuapradit introduced the steatocrit as a simple and rapid test for the evaluation of fat malabsorption (2-3). Acidification of fecal samples was shown to result in a major improwement of the method (4). This latter improvement is due to a better extraction of fecal fat, resulting in a better correlation between acid steatocrit results and chemically measured fecal fat (4).

Before this test can be widely used clinically, normal values for the acid steatocrit should be obtained especially during the first year of life, when a higher amount of fecal fat can be physiologic (5).

The present study was designed to establish the normal range of acid steatocrit values during the first year of life in term and premature babies, and to evaluate the possible influence of formula versus human milk feeding on fecal fat content as determined by the acid steatocrit.

\section{Patients}

For the present study 58 thealthy full-term infants $(0-1$ year), 31 girls and 27 boys were recruited at the well baby health control center.

16 healthy prematurely bon infants (mean gestational age: 204 days, range: 183-225 days), 6 girls and 10 boys were studied one week after they were on full enteral nutrition, this occurred at a mean postnatal age of 27 days (range: 15-52 days).

In order to evaluate the influence of feeding regimens, acid steatocrit results from 18 term infants of this group, 9 boys and 9 girls, aged between 40 and 120 days and exclusively milk-fed (formula or human milk), were compared. Human milk-fed infants all received their own mother's fresh milk, while formula-fed infants were given Nutrilon Premium (Nutricia,The Netherlands), a humanized cow milk formula with a farty acid composition similar to that of human milk (palmitic acid $18.1 \mathrm{~g} / 100 \mathrm{~g}$ fat and stearic acid $3.9 \mathrm{~g} / 100 \mathrm{~g}$ fat versus respectively $22.1 \mathrm{~g} / 100 \mathrm{~g}$ fat and $6.7 \mathrm{~g} / 100 \mathrm{~g}$ fat for human milk $(7)$. 


\section{Materials and Methods}

Fecal single stool samples were collecred and frozen at $-18^{\circ} \mathrm{Celsius.} \mathrm{Acid} \mathrm{steato-}$ crit measurements were performed using the merhod of Tran er al. (4). In short this method was as follows: stool $(0.5 \mathrm{~g})$ was diluted (1/4) with deionized water and thorougly homogenised making use of a $5 \mathrm{ml}$ Potter Elvehjem rissue homogenizer. Perchloric acid $5 \mathrm{~N}$ was added to the homogenate in a volume equal to $1 / 5$ of the homogenate volume. The resulting acid homogenate was mixed for 30 seconds making use of a standard Vortex mixer. The homogenate was aspirated into a $75 \mu \mathrm{l}$ plain glass haematocrit capillary. The capillary was subsequently centrifuged horizontally (13000 rpm. for $15 \mathrm{~min}$.) in a standard haematocrit centrifuge. After centrifugation, the lengths of the upper (fat) and the bottom (solid) layers were measured by means of a graduated magnifying lens. Steatocrit was calculated as the percentage of the fatty layer length over the sum of both the fatty and solid layers lengths. The variation coefficient of the acid steatocrit based on duplicate determinations in our laboratory was $5.1 \%$ (4).

The differences in acid steatocrit values between infants fed human milk and those fed formula were evaluated using the Willcoxon rank sum test.

\section{Results}

The acid steatocrit results of term and premature born children in the first year of life showed wide variability within the first 200 days ( \pm 6 months) of life, and decreased to values lower than $10 \%$ after the age of 6 months.

Fig.l shows the individual acid steatocrit results according to age and type of feeding. The acid steatocrit results in the first month of life showed very high values, with no differences between feeding regimens. All premature infants results were obtained before day 44 as indicated by the reference line on fig. 1. The figure shows that similar steatocrit results were found in premature and formula-fed infants under the age of 100 days. Later on acid steatocrit values dedine to values below $10 \%$ in practically all infants after the age of 6 months. Values of human milk-ted babies dropped earlier than those of formula-fed babies.

Regarding the fatty layer and solid layer columns length (fig. 3) we noticed that high acid stearocrit values always corresponded with a large fatty layer length with often a small solid layer length and on the contrary that low acid steatocrit values always corresponded to a small or absent farty layer length and a large solid layer length. 


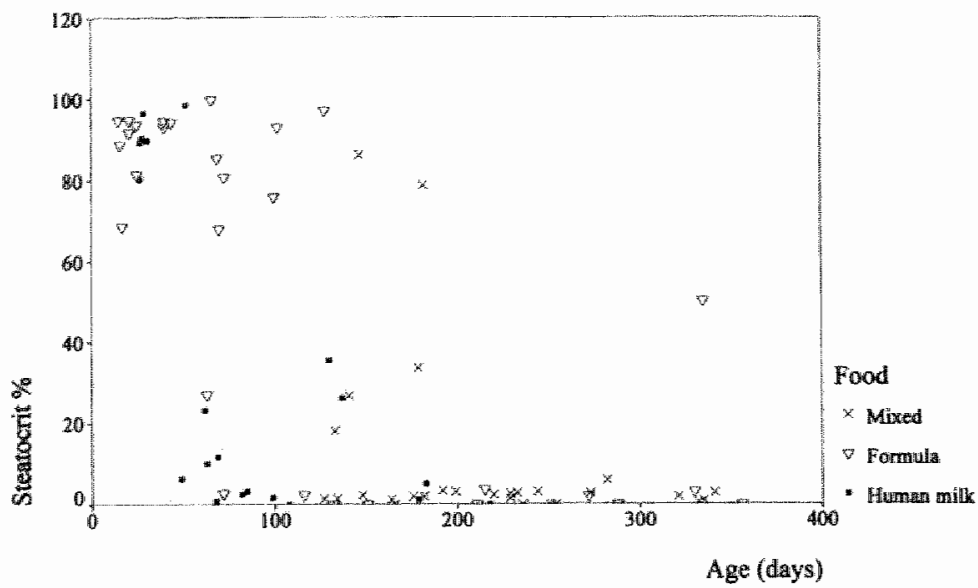

Figure $\mathbb{1}$. Individual walues of acid steatocrit during the first year of life with indicarion of the food regimen, showing normalisation after the age of six months. Results of the premature babies are shown at the lefi of the reference line.

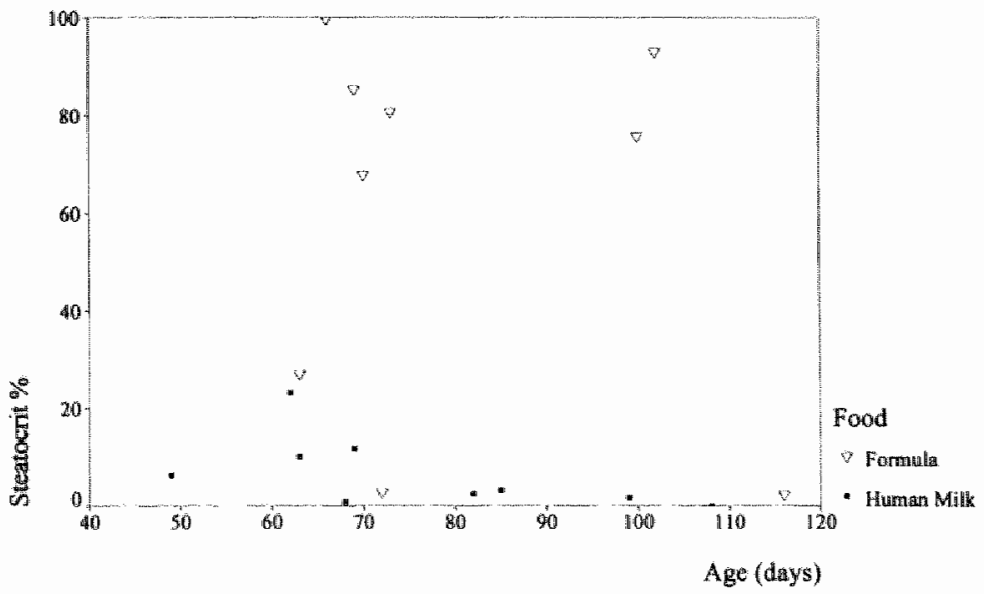

Figure 2. Acid stcatocrit results in exclusively human milk or formula-fed infants aged between 40 and 120 days. 


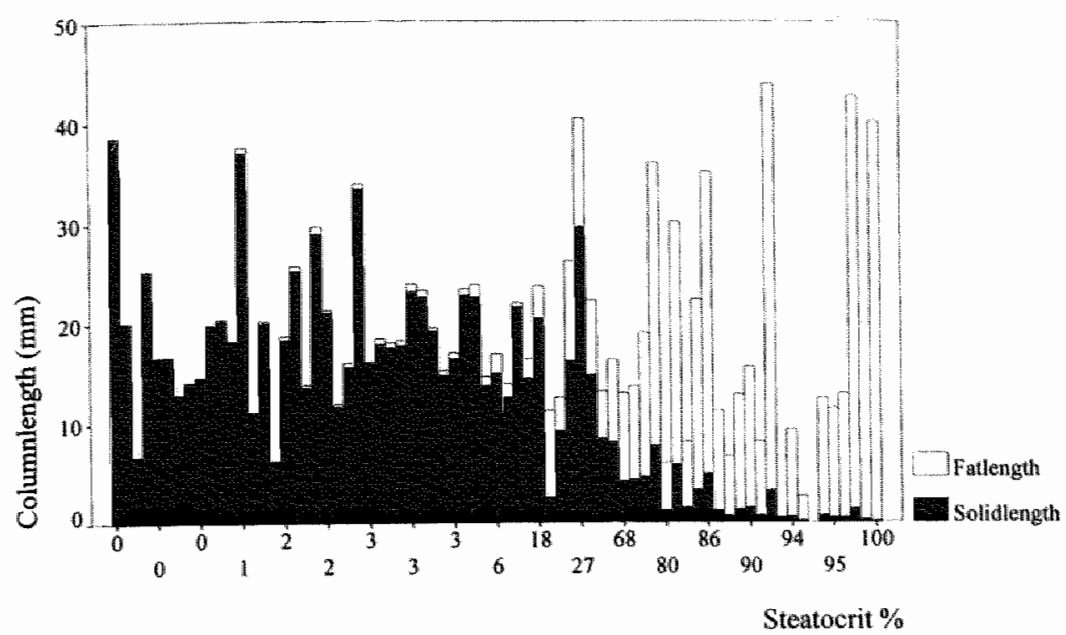

Figure 3. Fatlayer and solidlayer lengths related to acid steatocrit results.

The acid steatocrit values in the 18 exclusively milk-fed (formula or human milk) infants aged between 40 and 120 days, were significantly $(p<0.01)$ lower in human milk versus formula fed babies (fig 2). This difference was due to significantly $(\mathrm{p}<0.01)$ smaller fatty layer lengths in the human milk fed infants than in the formula fed infants, with similar solid layer lengths $(p>0.1)$ in both groups.

\section{Discussion}

The diagnosis of fat malabsorption is often very important in young infants when growth velocity is maximal. The method of Van de Kamer (1) is generally accepted for the diagnosis of fat malabsorption but, this method is difficult ro use, especially in infants when stools are often loose and watery and difficult to separate from urine. Therefore a simpler test such as the steatocrit micromethod (2) would be very welcome. Unfortunately, the method was considered unreliable by some authors (7). We could show that fat extraction was improved by acidification of fecal samples and that acid steatocrit results correlate much better with chemically measured fecal far (4).

In the present study the acid steatocrit values in healthy term and premature born infants were measured. 
When we consider our results, we notice a large variability of walues in the first 200 days of life. Several factors could be responsible for these findings. First, fat malabsorption in the first months of life is a well known previously described phenomenon (5). This fat malabsorption is considered physiologic and has been attributed to several possible factors such as reduced duodenal lipase activity (8), a reduced concentration of luminal bile salts (9), or the composition of the feeding fat (10).

The acid steatocrit values in premature infants are very high. This is in agreement with literarure data on balance studies in premature infants (11).

These high values are most probably due to both the presence of physiological higher amounts of fecal fat (high farty layers lengths) but also to the small lengths of the solid layers measured by the acid steatocrit determinarion of these premature and term born young infants receiving a fiber-free diet in the first postnatal months. These latter findings could explain the difference with previously published results of the steatocrit method without acidification (12) whereby fat remains as soaps in the solid layer (4) resulting in lower steatocrit results wich normalize at 45 days of age.In the present study acid steatocrit values only become normal after the age of 200 days. Concerning the significantly lower acid steatocrit walues in human milk-fed babies than in formula-fed babies, we noticed that the difference was due to significantly smaller fatty layer lengths in humanmilk-fed babies, while solid layer lengths were similar in the two feeding groups.As suggestions have been made in literature (13) that the total daily fecal output is comparable in infants who are fed either fresh human milk or formula milk, we conclude that fat in fresh human milk-fed babies is better absorbed than formula fat. This finding is supported by previous findings from several authors who showed absorprion of human milk fat to be much berter than formula far in young infants (14-15). We therefore consider the acid steatocrit a good tool for the evaluation of dietary fatabsorption.

\section{Conclusion}

Due to the presence of 'physiologic steatorrhea' high steatocrir levels can be found in normal infants during the first six months of life. Low results at this age point to normal fat absorption. After this age normal infants show low (below $10 \%$ ) steatocrit results. High walues are then indicative of fat malabsorption, lower acid steatocrit values were found in human milk-fed versus formula-fed infants, acid steatocrit should be useful for the evaluation of milk fat absorption in infants. 


\section{References}

1. Van de Kamer JH, Huinink HTB, Wejers HA. Rapid method for determination of far in feces. J Biol Chem 1949; 349-55.

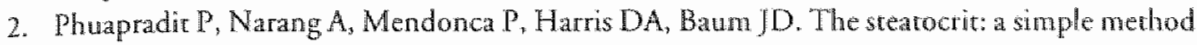
for estimaring stool far content in newborn infanrs. Arch Dis Child 1981; 56:725-7.

3. Colombo C, Maiavacca R, Ronchi M, Consalvo E, Amorerti M, Giunta A. The steatocrit: a simple method for monitoring far malabsorprion in parients with cystic fibrosis I Pediatr Gastroenterol Nurr 1987; 6:926-30.

4. Tran M, Forger P, Van den Neucker A, Strik J, Kreel wan B, Kuijten R. The acid steatocrit: a much improved method. J Pediar Gascroenterol Nutr 1994; 19: 299-303.

5. Weijers HA. Fat absorption in nomal infants and children. Thesis 1950 Urecht, The Nethertands.

6. Walthers MP, Kelleher J, Gilbert J, Littlewood JM. Clinical monitoring of steatorthoea in cystic fibrosis. Arch Dis Child 1990; 65:99-120.

7. Koletzko B, Mrotzek M, Eng B, Bremer HJ. Fatry acid composition of mature human milk in Germany. Am J Clin Nutr 1,988; 47:954-9.

8. Lebenthat $E$, Lee PC. Development of functionall response in human exocrine pancreas. Pediatrics $1980 ; 66: 556-60$.

9. Watkins JB, Szcrepantk P. Gould JB, Klein P, Lester R. Bile salt merabolism in the human premature infant. Gastroenterology 1975; 69: 706-13.

10. Hanna FM, Navarrete DA, Husu FA.Calcium-fatty acid absorption in term infants fed human milk and prepared formulas simulating human milk. Pediarrics 1970; 45: 216-24.

11. Shaw JCL. Evidence for defective skeletal mineralization in low birthweight infants: the absorption of calcium and fat. Pediatrics 1976; 57: 16-25.

12. Iacono $G$, Carroccio $A$, Cawataio $F$ et al. Steatocrit test: normal range and physiological vantiation in infants. J Pediatric Gastroenterol Nutr 1990; 11:53-7.

13. Arkinson SA, Bryan MH, Anderson $\mathrm{GH}$. Human mille feeding in premature infants: protein, fat and corbohydrate balances in the first two weeks of life. ) Pediatr 1981; 99: 617-24.

14. De Curris $M$, Sentere J. Rigo J. Puter G. Carbohydrate derived energy and gross energy absorption in premature infants fed human milk or formula. Arch Dis Child 1986; 61:867-70.

15. Williamson S, Finucane E; Ellis H, Gamsu HR. Enfect of heat treament of human milk on absorption of nirrogen, far sodium, calcium and phosphorus by premature infants. Arch Dis Child 1978; $53: 555-63$. 



\section{CHAPTER 6}

\section{Clinical use of acid steatocrit.}

A. Van den Neucker, N. Pestel" T. My Dung Tran", P.Ph. Forget",

H.J. Veeze" J. Bouquer, M. Sinaasappel".

'Department of Padatrics, University Hospital Matatridst and

"Sophia Children's Hospital Ronterdam. The Nethenlands

Acta Paediatr 1997: 86:466-9.

\section{Abstract}

Malabsorption of fat is an important gastrointestinal cause of malnutrition and growth retardation in childhood. The gold standard for the evaluation of fat malabsorption is the faecal fat balance method. The acid steatocrit method has recently been introduced as a simple method to evaluate faecal fat. The present study was aimed at evaluaring the acid steatocrit in clinical practice.

Faecal fat excretion and acid steatocrit results were determined in 42 children, half with and half without fat malabsorption.

Acid steatocrit results correlated significantly with both faecal fat excretion ( $\mathrm{p}<$ $0.01)$ and faecal fat concentration $(\mathrm{p}<0.001)$. Sensirivity and specificity of the acid steatocrit for the diagnosis of malabsorption was $90 \%$ and $100 \%$ respecively.

We consider the acid steatocrit method useful for the screening and monitoring of patients with stearorrhoea. 


\section{Introduction}

Malabsorption of far is the most important gastrointestinal cause of malnutrition and growth retardation in childhood. The detection of steatorrhoea is useful for the diagnosis of intestinal and pancreatic disease. The gold standard for the evaIuation of parients suspected of fat malabsorption is the far balance method whereby faecal fat is chemically measured according to the method of Van de Kamer (1). This method is cumbersome, laborious, expensive and often difficult to manage in children.

In 1981 Phuapradit et al. introduced a simple test to evaluate faecal fat content (2). Although some authors found this test quite reliable (3), orhers did not (4). As previously reported, substantial improvement of the method was obtained by acidification of faecal samples, acid steatocrit (AS) (5).

The present study was designed to compare the faecal far excretion with the acid steatocrit for the diagnosis and monitoring of fat malabsorption in children.

\section{Patients}

Forry-two children, 23 boys and 19 girls, aged between 6.5 months and 18 years (mean: 6.6 years) were selected for the study. All of these children were suspected. of fat malabsorption, on the basis of anamnestic and clinical parameters. The different diagnoses of our parients are given in Table 1.

Trable 1. List of dagnosis ( $n=42$ ).

Diagnosis

Cystic fibrosis

Mencal retardation

Recurrent diarrhoea

Falure to thrive

Coeliac disease

Inflammatory bowel disease

Shore bowel

Cholledochus cyste

Sucrase-isomaltase deficiency

Recurrent abdominal pain 
All children with cystic fibrosis (CF) had a normal daily fat intake according to the recommendarions of the "Dutch Nutritional Council'. The clinical and laboratory data concerning these children are shown in Table 2.

Table 2. Clinical and laboratory dara concerning the $20 \mathrm{CF}$ patients.

\begin{tabular}{|c|c|c|c|c|}
\hline $\begin{array}{l}\text { Age } \\
\text { (years) }\end{array}$ & $\begin{array}{l}A S \\
(\%)\end{array}$ & $\begin{array}{l}\text { Absorption } \\
\text { Coefficient } \\
(\%)\end{array}$ & $\begin{array}{l}\text { Pancreatic } \\
\text { Enzym } \\
\text { Substitution }\end{array}$ & $\begin{array}{l}\text { Pancreantic } \\
\text { Insufficientcy }\end{array}$ \\
\hline 4.6 & 31 & 48 & yes & yes \\
\hline 2.35 & 16.7 & - & yes & yes \\
\hline 7.16 & 18.7 & - & yes & yes \\
\hline 14.3 & 27.3 & 88 & yes & yes \\
\hline 5.91 & 5.75 & 98 & no & no \\
\hline 1.76 & 40.15 & 78 & yes & yes \\
\hline 1.29 & 17.35 & 91 & - & yes \\
\hline 7.02 & 27.65 & 78 & yes & yes \\
\hline 8.7 & 25.1 & 77 & yes & yes \\
\hline 4.85 & 6.1 & 94 & yes & yes \\
\hline 7.05 & 2.9 & - & - & no \\
\hline 11.58 & 21.45 & 79 & yes & yes \\
\hline 13.68 & 20.35 & 77 & yes & yes \\
\hline 12.47 & 9.9 & 93 & yes & yes \\
\hline 2.95 & 39.35 & 85 & yes & yes \\
\hline 18.73 & 31.95 & - & no & yes \\
\hline 5.95 & 18.6 & 85 & yes & yes \\
\hline 6.33 & 31.45 & 80 & yes & yes \\
\hline 0.55 & 83.3 & - & yes & yes \\
\hline 12.31 & 3.95 & - & - & yes \\
\hline
\end{tabular}

\section{Methods and Material}

Stools from 3 consecutive days from each parient were collected in separate containers, one container for each day. The stools were immediately frozen at $-18^{\circ}$ Celsius. Fat content in each 72 hours collection was determined by the titrimetric method described by Van de Kamer et al.(1). Acid steatocrit from a single stool sample on day 1 and from a sample out of the homogenized 72 -hours collection were determined by the method of Tran et al. (5). Faeces $(0.5 \mathrm{~g})$ was diluted (1/4) with deionized water and thoroughly homogenized making use of a 5 $\mathrm{ml}$. Potter Elvehjem tissue homogenizer. Perchloric acid $(5 \mathrm{~N})$ was added to the homogenate in a volume equal to $1 / 5$ of the homogenate volume. The resulting 
acid homogenate was mixed for 30 seconds using a standard Vortex mixer. The homogenate was aspirated into a $75 \mu \mathrm{l}$ plain glass haematocrir capillary. The capillary was subsequently centrifuged horizontally (13000 rpm. for $15 \mathrm{~min}$.) in at standard centrifuge. After centrifugation, the lengths of the upper (fat) and the bottom (solid) layers were measured by means of a graduated magnifying lens. Steatocrit was calculated as follows:

$$
\frac{\text { length of fat layer }(\mathrm{mm})}{\text { length of fat layer }(\mathrm{mm})+\text { length of solid layer }(\mathrm{mm})} \times 100
$$

In order to validate the diagnostic value of the acid steatocrit we studied two groups of patients, one with and one without steatorrhoea. We divided the parients according to previous clinical dara and fat excretion results, whereby a faecal fat excretion $\geq 3 \mathrm{~g} /$ day was considered as abnormal (6).

The investigators of the AS and of the faecal fat determinations following the method of Van de Kamer were unaware of both the diagnosis and each others results.

\section{Results}

Correlation coefficients between acid steatocrit results from either a single srool sample or from the sample taken from the 72-hours homogenized collection, and both the faecal fat excretion and the faecal fat concentration are shown in Table 3.

The sensitivity and the specificity of the acid steatocrit determination from either a single stool sample or a sample taken from the 72-hous homogenized collection, and of the faecal fat concentration, for the diagnosis of steatorthoea are shown in Table 4.

Table 3. Correlation berween the resuls of the AS from either a single stool sample and an sample from the homogenised stool collection and the results of both fat excretion and faecal far concentration in 42 children suspected of malabsorption.

Far excrerion

AS single stool

AS collection

$$
r=0.4(p<0.01)
$$

Fat concentration

$$
r=0.82(p<0.001)
$$

$$
r=0.68(p<0.001)
$$

$r=0.82(p<0.001)$ 
Table 4. Sensitivicy and specificity of the AS detemination from a single srool sample and from a homogenised stool collection sample and of the faecal far concentration, for the diagnosis of steatorthoew.

\begin{tabular}{lll}
\hline & $\begin{array}{l}\text { Sensirivity } \\
(\%)\end{array}$ & $\begin{array}{l}\text { Specificity } \\
(\%)\end{array}$ \\
\hline AS single stool & 75 & 84 \\
AS collecrion & 90 & 100 \\
Far concentration & 100 & 76 \\
\hline
\end{tabular}

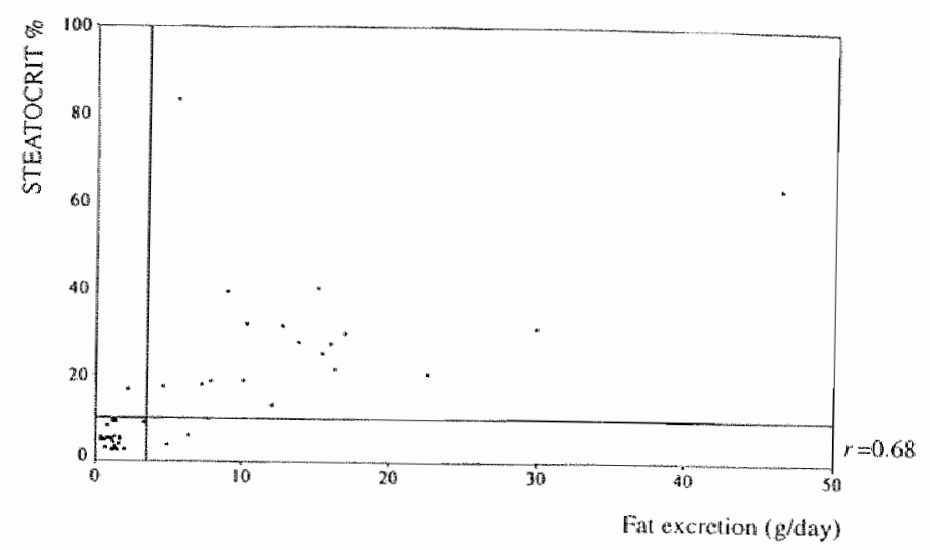

Figure 1. Relationship between AS results and fat excretion. Reference lines for AS ar $10 \%$ and for fat excretion ar $3 \mathrm{~g} / \mathrm{day}$.

The correlation coefficient between the AS results and the farcy layer lenghts in the present study was 0.83 whereas the correlation coefficient between the AS results and the solid layer lengrhs was 0.36 .

Figure 1 shows our AS results from the homogenized faecal collecrion sample related to the faecal fat excretion $(\mathrm{g} / \mathrm{day})$. The reference line for AS was set at the level of $10 \%(5)$, and the cut off reference line for the daily fat excretion was set at the level of 3 gram per day (6). As can be seen from the figure, one false positive and three false negative acid stearocrit results were found in our study popularion. Examining these results one should notice that they are very close to the reference lines: the false positive steatocrit result had a walue of $16 \%$ and the results of the faecal fat excretion corresponding to the false negative steatocrit results were 4.9 ; 6.4 and $7.7 \mathrm{~g} /$ day, and concern children aged 12,6 and 13 years respectively. 


\section{Discussion}

Since the faecal fat balance method as described by Wan de Kamer is cumbersome, expensive and unpleasant for all involved, there is a need for a simple test. Some authors reported the steatocrit micromethod described by Phuapradit as a simple method for monitoring far malabsorption (3), and reported a good correlation $(r=0.93)$ with the faecal fat excretion. Although others considered the steatocrit method of Phuapradit unreliable and mentioned the difficulty to delineate the fatty layer (4) and the impression that fat remains in the solid layer, as a problem of this method. This problem was solved by acidificarion of the faecal sample, whereby fat extraction is improved, and steatocrit results correlate much betrer with chemically measured faecal fat (5).

Our AS results correlate satisfactorily with chemically measured faecal fat concentrations and somewhat less, but still significantly, with faecal fat excretion. However, our correlation coefficient is lower than the correlation coefficient of the steatocrit without acidification as published in a previous study (3). We have no explanation for this discrepancy, and other authors also failed to reproduce these results (4).

The lesser correlation of the AS results with faecal fat excretion, by using a single stool sample instead of a sample from the homogenized collection can probably be explained by the variability of daily fat consumption in children, and by the fact that we compare two totally different entities: faecal fat excretion, which is expressed as faecal fat in grams per day and acid steatocrit which measures the ratio of the far layer on the sum of fat and solid layers. The latter determination probably measures mainly dietary fat, mostly occurring as soaps (7), liberated by acidification, whereas the chemical method also measures the endogenous fat from bacteria and shed cells.

To overcome the problem of the daily variability, one can sample the stool while a standardized daily amount of dietary fat is taken, or one can determine the mean of a few acid steatocrit results of samples taken on different days.

Our unpublished data show that in our laboratory the day-to-day variability of the AS results from three stool samples taken on three consecurive days of adults (who have a more constant daily fat intake than children) is rather small. The standard deviation of the differences ranged between $13.6 \%$ and $0.23 \%$ with a mean of $5.2 \%$.

The one false positive result of the AS concerned a patient with cystic fibrosis who was treated with pancreatic enzyme substitution therapy. This AS result of $16 \%$ is only slightly elevared considering the values obtained in cystic fibrosis patients on subsritution therapy, which are mostly between 20 and $30 \%$. 
The three false negative results of the acid steatocrit can probably be explained by the fact that there are no reference values for the normal faecal fat excretion according to age. Faecal fat excretion higher than $4.5 \mathrm{~g} / 24$ hours is considered patho$\operatorname{logic}(6,8)$ for children and adolescents, whereas other authors consider $7 \mathrm{~g} /$ day the upper limit of normal faecal fat excretion in adults (9). The reference line for normal daily faecal fat excretion varies clearly with age and dietary fat intake as previously suggested by Williams (8). Taking account of these remarks, the fat excretion studies of $2 / 3$ patients with false negative steatocrit results could, due to their ages (1.2 and 13 years), still be considered 'normal' and in agreement with AS results.

\section{Conclusion}

Acid steatocrit results are highly correlated with the chemically measured faecal fat concentration and significantly correlated with the faecal fat excretion. Although single sample acid steatocrit results are slightly less sensitive and specific than other measured parameters for the diagnosis of steatorrhoea, acid steatocrit measured in the stool samples taken from the homogenized collecrion compare favourably with the faecal fat concentration. From this point of view we consider that the acid steatocrit method could be useful for the screening and monitoring of patients with pancreatic steatorrhoea, using the result of a stool sample from an homogenised 3-day collection or the mean of the results of single stool samples from three different days. The faecal fat balance method is needed whenever one wishes to evaluate the fat absorption coefficient.

\section{References}

1. Van de Kamer JH, Huinink HTB, Weyers HA. Rapid method for determination of fat in facces. I Biol Chem 1949; 1773349-55.

2. Phuapradit P, Narang A, Mendonca P, Harris DA, Baum JD. The steatocrit: an simple merhod for estimating scool fat content in newborn infants. Arch Dis Child 1981; 56:725-7.

3. Colombo $C$, Maiavacca $R$. Ronchi $M$, Consalvo E, Amorerti M, Gunta A.The steatocrita simple method for monitoring fat malabsorption in parients with cystic fibrosis. I Pediatr Gastroenterol Nutr 1987;6:926-30.

4. Walters MP. Kelleher J, Gibert J. Littelwood JM. Clinical monitroning of steatorrhoca in cystic fibrosis. I Pediatr Gastroenterol Nutr 1990; 65:99-102.

5. Tran M, Forget P, Van den Neucker A, Strik J, Kreel van B, Kuijten R. The acid stearocrit: a much improved method. J Pediatr Gastroenterol Nutr 1994; 19: 299-303.

6. Navarro J, Schmicz J. Gastroenterologie pédiatrique. Flammarion Médicine Sciences, Paris 1986. 
7. Quinlan PT, Lockron \$, Irwin J, Lucas AL. The relationship berween stool hardness and stool composition in brexs-and formula-fed infanes. I Pediatr Gastroenterol Nutr 1995; 20:81-90.

8. Willams HH, Endicon EN, Shepherd ML, Gabrath H, Macy IG. Fat excremon by normal childien. J Mutr 1943; 25,379 .

9. Bai JC Andrish A, Matelo G, Martinez C Vazquez $H$, Boerr L, Sambuelli A. Faecal Far concentration in the differential diagnosis of steatorhoea. Am. J. Gastroenterol. 1989; 27-30. 


\title{
CHAPTER 7
}

\section{Acid Steatocrit: A reliable screening tool for steatorrhoea.}

\author{
AM Van den Neucker ", EM Kerkuliet ". PMVM Theunissen ", P-Ph Forget \\ "Department of Pediatrics, Wriversity Hospital Mawaricht, \\ 'St. Jans Gasthuis, Wert, "Atwiam Mediscb Centrum. Heerlew \\ The Netherlatuds.
}

Acta Paediatr 2001; $90: 873-5$.

\begin{abstract}
This study compared the acid steatocrit (AS) results of healthy children with those of sick children with and without gastrointestinal involvement. Stool samples of 166 children were investigated, comprising 50 healthy children, 26 asthma patients, 90 patients with gastrointestinal problems divided into: 34 treated cystic fibrosis (CF) patients with exocrine pancreatic insufficiency, 16 untreared coeliac disease (CD) parients and 40 patients with various gastrointestinal problems.

The median values $\left(5^{\text {th }}-95^{\text {th }}\right.$ percentile $)$ of AS results were $3.3 \%(0.0-21 \%)$ for healthy children, $4.5 \%(1.8-22.5 \%)$ for asthma patients, $24.7 \%$ (2.6$68.2 \%$ ) for treated CF patients with exocrine pancreatic insufficiency, $19.8 \%(3$ $77.7 \%)$ for untreated $C D$ patients and $5.5 \%(1.8-29 \%)$ for partients with various gastrointestinal diseases.

The AS results of treated CF patients with exocrine pancreatic insufficiency and untreated CD patients are similar and significantly higher than those of healthy children and asthma patients. AS can be considered to be a reliable tool in the screening for steatorthoea in pediatric patients.
\end{abstract}




\section{Introduction}

Fat malabsorption is an important cause of poor growth in infancy and childhood. The 72-hours faecal fat balance according to the method of Van de Kamer is still considered to be the gold standard for the diagnosis of fat malabsorption (1). In 1981 Phuapradit described the steatocrit method as a simple procedure for estimating stool fat content in newborn infants (2). Acidification of the faecal homogenate has been shown to improve the reliability of steatocrit results $(3,4)$. Several clinical studies have shown the acid steatocrit (AS) to yield a clinically useful sensitivity and specificity for the detection of steatorrhoea $(5,6,7)$.

Reported studies using the AS method concerned mainly heal thy infants, cystic fibrosis patients with pancreatic insufficiency and adult patients $(5,6,7)$. The present study was undertaken to compare the AS results of healthy children with those of sick children without (patients with asthma) and with (CD, $\mathrm{CF}$, various) gastrointestinal involvement.

\section{Material and Methods}

Stool samples from 166 children were taken and immediately frozen at $-18^{\circ} \mathrm{C}$. AS was performed using the method of Tran et al. (3).

The children were divided into five groups:

1. 50 healthy children $(25 \mathrm{M}, 25 \mathrm{~F}$ ) with a mean age of $3.9 \mathrm{y}$ (range $0.5-3.8 \mathrm{y}$ );

2. 26 parients with asthma (17M, 9F) with a mean age of 5.9 y (range $0.9-17.6$ y);

3. $34 \mathrm{CF}$ parients $(20 \mathrm{M}, 14 \mathrm{~F})$ with a mean age of 7.5 y (range $0.5-18.7 \mathrm{y}$ ). These patients have exocrine pancreatic insufficiency and receive pancrearic enzyme substitution therapy;

4. 16 patients with symptomatic CD $(6 \mathrm{M}, 10 \mathrm{~F})$ with a mean age of $4.5 \mathrm{y}$ (range $0.9-16.6 \mathrm{y})$. These patients were examined before treatment with a gluten free diet and had positive antigliadin and antiendomysium antibodies and subtotal villous atrophy at duodenal biopsy. They presented with failure to thrive and improved after gluten-free diet;

5. 40 patients $(22 \mathrm{M}, 18 \mathrm{~F}$ ) with a mean age of $4.6 \mathrm{y}$ (range $0.5-14.6 \mathrm{y}$ ), with various gastrointestinal problems (Table 1).

All data were managed with the SPSS statistical program. The Mann-Whitney $\mathrm{U}$-test for independent samples was used for comparing means. 


\section{Results}

The median AS values of healthy children, astma patients and patients with gastrointestinal diseases, other than CF or symptomatic CD before trearment, were lower than 10\% (Table 2). The mean AS values of CF parients with enzyme substitution therapy and symptomatic coeliac patients before treatment were significantly higher than those of healthy children and astma parients $(p<0.0001)$.

Compared with healthy children, patients with "various gastrointestinal disease' showed only a slightly increased mean AS result $(p=0.04)$. In this group there were three outliers: one patient with billiary atresia and two patients with short bowel disease. The individual AS results of these outliers were 18.7\%, 29\% and $36.1 \%$, respecrively. After exclusion of these outliers, the mean AS results did not differ from that of the healthy controls $(p=0.11)$.

The mean AS results of treated CF patients and of untreated coeliac patients were not significantly different $(p=0.5)$. Comparing the individual AS results of treated CF patients and untreated coeliac patients, $76 \%$ and $75 \%$ of these parients respectively, showed a value above $10 \%$.

Regarding individual AS results within the different groups (Fig. 1), one child in the group of healthy children showed an unexplained high value of $44.8 \%$.

Table 1. Diagnoses of sick control patients $(n=40)$ with various gastrointestinal problems.

\begin{tabular}{lc} 
Diagnosis & $N$ \\
\hline Disaccharidase deficiency & 1 \\
Short bowel syndrome & 2 \\
Diarnoea (infectious, toddler's diarrhota) & 12 \\
Failure to thrive (endocrine, nutritional deficiency) & 13 \\
Biliary atresia & 1 \\
Abdominal pain & 3 \\
Inflammatory bowel disease & 1 \\
Parasitosis & 2 \\
Eating disorders & 2 \\
Cow's milk protein intolerance & 2 \\
Codiac disease, on diot & 1
\end{tabular}




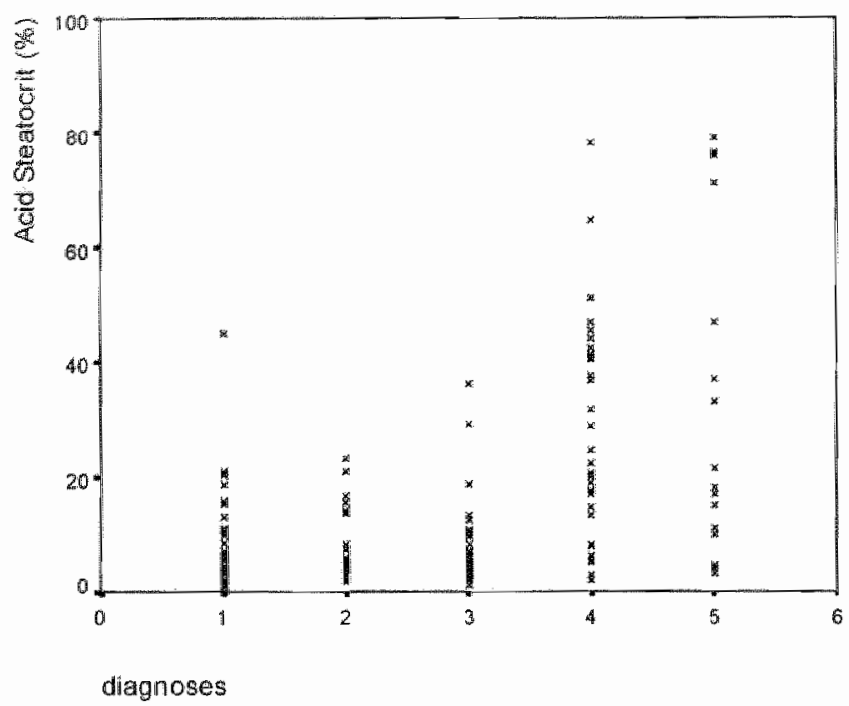

Figure 1. Acid stearocrit results of 1: healthy children; 2: asthma parients; 3 : various gastrointescinal disease; 4 : cystic fibrosis patients; and 5: coeliac disease parients.

Table 2

\begin{tabular}{lcll}
\hline Subjects & AS $(\%)$ & AS $(\%)$ & AS $(\%)$ \\
& median & 5 th percentile & 90 th percentile \\
\hline Healthy chidren & 3.3 & 0.0 & 21 \\
Asthma parients & 4.5 & 1.8 & 22.5 \\
CF patients & 24.7 & 2.6 & 68.2 \\
CD patients & 19.8 & 3 & 77.7 \\
Batients with various G.l-disease & 5.5 & 1.8 & 29
\end{tabular}

AS: acid steatrocit: CF: cystic fibrosis; $C D$ : coeliac discase; $G 1$ gastrointestinal

\section{Discussion}

The results show that the mean AS results of children with treated exocrine pancreatic insufficiency due to CF and of children with $C D$ with gastrointestinal symptoms before treatment with a gluten-free dier, were both significantly increased compared to the mean AS resulrs of healthy children. The mean AS results of asthma patients and healthy children were comparable.

This confirms that patients with exocrine pancreatic insufficiency due to $\mathrm{CF}$ while on enzyme substirution therapy keep some degree of fat malabsorption as reported in the literature $(8,9)$, and coeliac patients with the typical gastrointesti- 
nal symptoms such as weight loss, diarrhoea, abdominal distention and growth retardation often show steatorrhoea. In his work on $\mathrm{CD}_{n}$ Dicke suggested steatorhoea in these patients to be due to malabsorption associated with mucosal atrophy but also mentioned the difficulty at that time in excluding pancreatic fibrosis in these patients (10).

Other authors such as Bo-Linn and Fordtran (11), and Bai et al. (12) similarly consider steatorrhoea in coeliac patients to be due to mucosal disease and nor to pancreatic disease. Recently reported studies $(13,14,15,16,17)$ however show that pancreatic insufficiency contributes to steatorrhoea in CD patients in $24 \%$ (18) to $33 \%$ (19) of the cases.

The present results show that the mean and median values of faecal fat content as measured by the AS in CF patients while on substiturion therapy and in symptomatic coeliac parients before treatment are very similar, which could be explained by pancreatic involvement in borh diseases. If one accepts $10 \%$ as cut-off value for the AS, as suggested by Tran et al. (3) three quarter of both groups appear to show sreacorrhoea. These results are in agreement with literacure dara $(8,9,17,18,20,21)$.

Although the steatocrit test may be a good screening test for detecting $\mathrm{CD}$, it is well known that steatorrhoea is not always present in $\operatorname{CD}(22,23)$, and that serological methods are the best screening methods available $(24,25)$. Furthermore, it remains unclear wherher steatorrhoea in $C D$ is mainly of intestinal or pancreatic origin, and whether the pancreatic involvement is primary of secondary to poor enterohormon secretion linked to mucosal atrophy. $(26,27)$

In the group of patients with various gastrointestinal problems the higher values of AS were due to results in two patients suffering from short bowel clisease and one patient with biliary atresia. Faecal fat balance had shown these patients to have steatorrhoea.

Most of the other patients in this group had either diarthoea (infectious or toddler's diarrhoea) or failure to thrive not due to gastiointestinal clisease and showed normal steatocuit results.

\section{Conclusion}

Acid Steatocrit results are similarly low in healthy children and in patients with asthma. Only patients presenting with gastrointestinal disease known to be associated with steatorrhoea show abnormally high faecal fat content as measured by the acid steatocrit. The Acid Steatocrit can be considered to be a reliable tool in the screening for steatorrhoea in pediatric patients. 


\section{References}

1. Van de Kamer JH, Huinink HTB, Weipers HA Rapid method for determinarion of fat in faecers. J Biol Chem 1949:349-55.

2. Phuapradic P, Narang A, Mendonca P, Haris DA, Baum JD. The stearocrit: a simple method for moniroring fat malabsorption in patients with cystic fibrosis. Arch Dis Child 1981; 56: 725-7.

3. Tran M, Forget $P$, Van den Neucker $A$, Strik J, Wan Kred B, Kuijten R. The acid steatocrit: a much improwed method. J Pediatr Gastroenterol Nurr 1994; 19: 299-303.

4. Tran M, Forger I?, Van den Neucker A, Van Kreel B. Improwed steatocrit results obtained by acidification of faccal homogenate ane due to improved fat extraction. I Pediarr Gastroentetol Nutr 1996;22: 157-60.

5. Anamn ST, Josephson SA, Toskes PP. Acid steatocrit: a simple, rapid gravimetric method to determine steatorthoea. Am J Gastroenterol $1997 ; 92: 2280-4$.

6. Van den Neucker A, Pestel M, Tran MD, Farger PPh, Veeze HJ, Bouquer J, Sinaasappel M. Clinical use of acid steatocric Acta Pacdiar 1997; 86: 466-9.

7. Van den Neucker A, Forget P, Veneberg JA, Schutren B], Van Kreel B. Acid steatocrit during infancy. Acta Paediatr 1996;85:1153-5.

8. Kalivianakis M, Minich DM, Bijleweld CMA. Van Aalderen WMC, Stellard F" Laseur M, et al. Far malabsorption in cystic fibrosis parients receiving enzyme replacement therapy is due to impaired intestinal uptake of long-chain fatty acids. Am I Clin Nutr 1999; 69: 127-34.

9. Di Magno EP, Go VLW, Summerskill WHJ. Impaired cholecystokinin-pancreozymin secreton, intraluminal dilution, and maldigestion of fat in sprue. Gastroenterology 1972;63:25-32.

1.0. Dicke W K Coeliac disease, investigation of the hamful effects of certain types of cereat on parients with coeliac disease; Utrechr 1950.

11. Bo-Linn, Fordtran JS. Faecal fat concentration in patients with steatorthoea. Gastroenterol 1984; 87:319.22.

12. Bai JC, Andrüsh A, Matelo G, Martinez C, Vazquez H, Boerr L, Sambuelli A. Faecal fat concentration in the differential diagnosis of steatormoea. Am I gastroenterol 1989;84:27-30.

13. Rabinson $\mathbb{P}^{\text {, Sly } \mathrm{P}}$. High dose pancreacic enzymes in cystic fibrosis. Arch Dis Child 1990; 65: $311-2$.

14. Regan DT, Di Magno EP. Exocrine pancreatic insufficiency in celiac sprue: a canse of treatment failure. Gastroenterology 1980;78:484-7.

15. Ansaldi N, Oderda G. Exocrine pancreatic insufficiency in celiac sprue. Gastroenterology 1981; 80:883.

16. Delco F. ELSerag HB, Sonnenberg A. Celiac sprue among US milicary vererans: associated disorders and clinical manifestations. Dig Dis Sci 1999; 44:966-72.

17. Nousia-Arvanitakis $S$, Karagiozoglou-Lamboudes: T, Aggouridaki C, Malaka-Lambrellis E, Galli-Tsinopoulou A, Xefteri M. Influence of jejunal morphology changes on exocrine pancreatic function in celiac disease. I Pediart Gastroenterol Nutr 1999; 29:81-5.

18. Pert F, Pastore M, Festa V, Clemente R, Quitadamo M, D'altilia MR, et al. Intra duodenal lipase activity in celiac disease assessed by means of ${ }^{13} \mathrm{C}$ mixed atriglyceride breath test. I Pediarr Gastroenterol 1998; $27: 407-10$.

19. Carroccio A, Iacono G. lpolito S, Verghi F, Cavataio F, Soresi M, et al. Usefulness of faecal elastase-1 assay in monitoring pancreatic function in childhood coeliac disease. Ital I Gastroenterol Hepatol $998,30: 500-4$ 
20. Carrocio A. Lacono G, Lerro P. Cavario F, Malorgio E, Soresi M er al. Role of pancreanic imparement in growth recovery during gluten-free dier in chuldhood celiac discase. Gastroenterology 1997; 112:1839-44.

21. Iacono G, Carroccio A, Montalto G, Caratato E, Balsamo V, Notabartolo A. Stearocrit test after a standard fatry med: a new simple and sensirive test to detect malabsorption. J Pediatp Gastroenterol Nutr 1991; 13:161-7.

22. Anderson CM. Gracey M. Burke V. Coeliac Disease. Arch Dis Child 1972; 47:292-298.

23. Pournelle ND, Ciclitira PJ. Review article: coeliac disease and iss managennent. Alinent Pharmacol Ther 1999; $13(1): 1-13$.

24. Russo PA, Charrand LJ, Seidman E. Compararive andysis of serologicscreening rests for dhe intrialdiagnosis of celiac disease. Pediatrics $1999 ; 104(1): 75-8$.

25. Vitoria IC, Arrieta A, Arranz C. Ayesta A, Sojo A, Maruri N, Garcia-Masdevall MD. Antibodies to gliadin, endomysium, and tissue trangglutaminase for the diagnosis of coeliac disease I Pediatr Gastroenterol Nutr 1999; $29(5): 571-4$.

26. Gomez JC. Exocrine pancreatic insufficiency in celiac disease. Gastroencerol 1998; 114: $621-22$.

27. Carroccio $A$, lacono $G$, Montalto $G$, Cavataio $F$, Di Marco $C$, Balsamo V. Notar bar tolo A. Exocrine pancreatic function in children with coelias disaese before and after glutenfree diet. Gut 1991:32: 796-9. 



\section{CHAPTER 8}

\section{Discussion and conclusion}

Growth and development are the most important features of childhood (1). Energy is needed for this purpose and this energy is provided by our food. Per gram of food constituents, fat provides the highest amount of calories (lipid: 9 $\mathrm{Kcal} / \mathrm{g}$ compared to protein and carbohydrates: $4 \mathrm{Kcal} / \mathrm{g}$ ), and therefore fat malabsorption interferes strongly with growth and development in childhood (1, 2).

To prevent interference with growth it is important for the paediatrician to be able to diagnose fat malabsorption early and, as it concerns children, in a non-invasive way. If dietary fat absorption or digestion is disturbed and fat intake remains unchanged, fat excretion will increase. Determination of faecal fat seems to be the most appropriate investigation to perform. Until now determination of the fat absorption coefficient by the 72 -hour faecal fat balance and faecal fat determination by the chemical titrimetric method of Van de Kamer has been considered the gold standard for diagnosing fat malabsorption (3).

However, this method has many disadvantages: the variability of the daily fat intake, the difficulty to collect stools, the toxicity of the solvents used for the technique itself and incomplete faecal far extraction are well recognized problems ( 4 , $5,6,7)$.

Due to these inconveniences, faecal fat balance in clinical practice is often reduced to the determination of the daily faecal fat excretion as a measurement of steatorrhoea: excessive loss of fat in the stools. In adults, $6-8 \mathrm{~g}$ daily faccal far is considered the upper limit of normal (8). In children the limit of normal daily faecal fat excretion varies with age; more than $3 \mathrm{~g}$ of daily faccal fat is considered to be abnormal, but in young infants higher amounts of faccal fat are often found due to immarurity of the pancreas, to low duodenal concentration of intra-luminal bile salts, or to the variable composition of dietary fat. Faecal fat excrevion in adolescents is more comparable to that found in adults $(5,9,10,11,12)$.

It is obvious that this gold standard is far from ideal. Many orther rests for diagnosing far malabsorption have consequently been described and are used clinically. These different tests are summarized and discussed in chapter 1. 
These tests can be divided in to two groups:

1 -tests evaluating the presence of faecal fat, such as the fat balance technique, the microscopic examination of fat droplets in stool specimens, the near-infrared reflectance analysis, the NMR measurement of faecal fat, and the steatocrit method,

2 -tests evaluating lipid absorption such as fat loading test, the vitamin $A$ loading test, the determination of plasma beta-carotene and radioactive or isotope labelled fat absorption tests $(3,8,13,14,15)$.

As all these tests have their shortcomings, it is necessary for the clinician to make a good choice for routine clinical use. Such a rest should be accurate, easy to perform, repeatable, non-invasive, and with a good specificity and sensitivity.

The stearocrit method as described in 1981 by Phuapradit et al. seemed to satisfy these needs (16). We introduced this method in our laboratory, but despite the promising results of some authors this method was reporred not to be reliable by Walters et al. $(17,18,19)$. The delineation and subsequent measurement of the three different layers in the haematocrit capillary, obtained after centrifugation of the faecal homogenate seemed to be the main problem. Different authors tried to improve the method by adding sand to the homogenate or by using sophisricated meters $(20,21)$. In our laboratory we ameliorated the test by acidification and demonstrated that 'acid steatocrir' results correlated better than the original test with results of the chemical titrimetric method of Van de Kamer and that its variation coefficient was lower chapter 2.

It is understandable that acidification ameliorates fat extraction, as non-absorbed dietary fats mainly occur as soaps in the faeces. This has been clearly demonstrated by Tran et al. $(22,23)$. Other authors confirmed this improvement $(24$, 25).

To demonstrate that this improved 'acid steatocrit' was at least as reliable as the other tests routinely used for evaluation of faecal fat, we compared the results of the AS with the results of faecal fat determination by the chemical titrimetric method of Van de Kamer and by NIRA. We compared the results of these three tests with that of faecal energy as measured by the bomb-calorimeter (chater 3). We did not compare our AS results with results of the microscopic examination of the stool specimen for fat droplets. This test is considered a reliable test for evaluating faecal fat as reported in the last edition of Nelson's textbook of Pediatrics, but in 1948 Van de Kamer found this test already unreliable after comparison with the results of his method $(2,3)$.

We demonstrated that the results of the AS method were comparable to those of these other tests estimating faecal fat. The advantage of the AS in comparison with these other tests is its cheapness and simplicity. The NIRA apparatus is indeed very expensive and the method of Van de Kamer is laborious and dangerous for the laboratory personnel through inhalation of the toxic solvents. By its sim- 
plicity and cheapness the AS test is also suitable for countries with restricted public health budgets.

As the gold standard for the diagnosis of fat malabsorption is the faecal far balance technique with 72-hour stool collection, we had to demonstrate that a single stool sample could give similar information to a stool collection. For this purpose we examined stool samples from cystic fibrosis patients with steatorrhoea and from healthy children. We determined faecal lipid, water, nitrogen and energy concentration, and compared our results with those obtained from three-day stool collections as reported in literature (chapter 4 ). Why we compared our results to those reporred in the literature was because most of our patients and healthy children, or their parents, were unwilling to collect stools for three days. Most of them had no problem with the delivering of different stool samples for AS determination. In his thesis in 1950 Weijers already mentioned the difficulty to collect stools, especially in young children and he also described a pot specially made for this purpose by the 'Société Céramique Maestricht' (5). Furthermore, we know from our own experience and from colleagues that many stool collections performed at home are incomplete and therefore give inaccurate informarion.

Our study shows that, concerning concentrations, single stool sample results for lipid, water, nitrogen and energy are comparable wirh those obtained by stool collections and that increased fat and energy losses are clearly apparent from data provided by single stool samples.

The value of faecal far concentration instead of the total amount of daily faecal fat excretion for the diagnosis of steatorrhoea is discussed in the literature. Some authors believe that high faecal fat concentration suggests the presence of pancreatic or biliary steatorrhoea, but that faecal fat concentration might not be sensitiwe enough to detect stearorrhoea of intestinal origin. The diluting effects of coexisting fluid malabsorption could diminish the faecal fat concentration (8). This suggest the AS method might be a better alternative than the faecal fat concentration as in the AS method the water component is not included in the equation; the results being calculated from the amount of faecal fat and of faecal solid omitting faecal water. Some literature data support our opinion (25). Comparison of AS results with results of more specific tests for the investigation of intestinal lipid absorption, such as isotope labelled fat absorprion tests, can possibly answer this question.

Steatorrhoea can be normal in neonates and young infants (5). We had to determine the duration of this neonatal steatorrhoea, because discrimination between normal and pathologic steatorrhoea is impossible during this period. For this purpose we examined stool samples from healthy infants during the first year of life (chapter 5). Our AS results were low (below 10\%) in healthy children from the age of 6 months. Before this period results showed wide variabiliry. After the 
age of 6 months increased values are indicative of fat malabsorption, whereas before the age of 6 months this can also be due to the normal neonatal steatorrhoea. Low results before the age of 6 months on the other hand suggest that fat absorption is normal providing that fat intake is sufficient. Furthermore, our results showed significantly lower results in the group of infants fed human milk than in the formula-fed group, suggesting that the AS method could be useful for investigation of dietary fat absorption in order to improve the composition of formula fat.

In chapter 6 we compared results of a three-day faecal fat balance with AS results obtained from a single stool sample and from a sample taken from the homogenized stool collection in a group of patients with and without steatorrhoea. The AS results were highly correlated with the chemically measured faecal fat concentration and significantly with the daily faecal fat excretion. Single stool sample AS results are slightly less sensitive and specific than AS results from samples taken from the homogenized stool collections. But, single stool sample AS results compare favourably with the chemically measured fat concentration from these collections. The difference between the single sample results and the results from the homogenized collections can be explained by the wariability of the daily fat intake in children. We can try to prevent this problem by keeping the amount of ingested fat stable, but especially in small children this will be difficult, unless. tube feeding is used.

The AS method can be useful for the monitoring of steatorrhoea in cystic fibrosis patients on enzyme substitution therapy. Clinicians dealing with these patients know that during the stool collection period parents and patients try to do their best to follow the physician's instructions and their usual diet is often much more irregular than during the collection period. As stool samples can be taken frequently at different moments in time, we may have a more realistic idea of their fat malabsorption than we would have by performing an annual faecal fat balance. This can be advantageous for monitoring enzyme substiturion therapy. Whether or not this method of monitoring stearorthoea will result in a better nutritional status of our cystic fibrosis patients is difficult to evaluate due to the confounding effects of respiratory infections and the natural evolution of the disease. We have shown that the AS method is useful in demonstrating the effect of therapeutic interventions on fat malabsorption in CF patients $(26,27)$.

We thus demonstrated that the AS method is clinically useful for the diagnosis of fat malabsorption and the monitoring of steatorrhoea in cystic fibrosis patients.

In chapter 7 we evaluated the screening value of the AS method. We determined the AS in different groups of children: healthy children, asthma patients and patients with gastrointestinal diseases. This last group was subdivided in cysric fibrosis parients with exocrine pancreatic insufficiency while on substitution therapy, coeliac disease patients before treatment with gluten-free diet, and pa- 
tients with warious gastrointestinal diseases. The AS results were similarly low in heall thy children and asthma parients and only elevated in parients suffering from gastrointestinal diseases known to be associated with steatorrhoea: cystic fibrosis patients with exocrine pancreatic insufficiency on enzyme substitution therapy, coeliac disease patients before treatment, and parients with billary steatorrhoea.

The similarity of the results found in cystic fibrosis and coeliac disease patients is remarkable. Steatorhoea in cystic fibrosis parients is caused by pancreatic insufficiency and intestinal malabsorption while in coeliac disease fat malabsorption was believed to be mainly caused by intestinal malabsorption. Our results suggest the same origin of their fat malabsorption and this is in agreement with recent data in the literature $(28,29)$.

In conclusion we believe AS method to be a clinically useful test ro screen for steatorrhoea in childhood from the age of 6 months up to adulthood. As in all tests dealing with faecal fat for the diagnosis of steatorrhoea, an adequate intake of dietary fat is the only precaution. Because of its cheapness and simplicicy the test is also useful in countries with a restricted public health budget. Its repeatability makes it useful for the monitoring of steatorthoea and for the evaluation of the effects of new therapeutic interventions. The faecal fat balance and more specific and invasive investigations are available for the quantitative evaluarion of fat malabsorption.

\section{References}

1. Betrman RE, Kliegman RM, Jenson H B (2000). Nelson Textbook of Pediatrics; $16^{\text {th }}$ Ediuon. W.B. Saunders Company, Philadelphia USA.

2. Nederlandse voedingsmidelentabel. Voorlichingsbureat voor voeding. 1999.

3. Van de Kamer JH, Huinink H TB, Weyers HA. Rapid method for detcrninarion of fat in feces. I Biol Chem 1949:177:349-55.

4. Sinaasapel M, Howwen R.HJ, Van der Lag J, Gysbers CFM, Taminau JAMJ, Van den Berg JWO. The faecal far balance and the ${ }^{13} \mathrm{C}$-mixed rriglyceride breath resi; diagnostic precision as determined in repeated studies in patients with cystic fibrosis Abstrace $22^{\text {th }}$ Furopean $\mathrm{CF}^{2}$ Conference, Betin 1998.

5. Weijers HA. Fat absorption in normal and abnormal infants and children. Thesis 1950 Utrecht The Nerhelands.

6. Bekers $\mathrm{O}$, Postma C, Lombarts AJPF. Determination of faecal fat by nea in intrated spectroscopy. Eur ) Clin Chem Clin Biochem 1995; 33: 83-6.

7. Jeejecbhoy $\mathrm{KN}$, Ahmad 5 , Kozak $\mathrm{C}$. Determination of fecal fats containing both modiun and Jong chain riglycerides and farty acids. Clin Biochem 1970; 3: 1.57-63.

8. Fine KD, Schiller LR. AGA technical review on the evaluation and management of chronic diarrhea. Gastroentmology 1999; 116: 1464-86. 
9. Williams $H \mathrm{H}$, Endicon EN, Shepherd ML, Galbraith $H, M a c y I G$. Fat excretion by normal children. I of Nutrition $1943 ; 25: 379-87$.

10. Leberthat $\mathrm{E}$, Lee $\mathrm{PC}$, Dewelopment of functional response in human exocrine pancreas. Paediatrics $1980 ; 66: 556=60$.

11. Warkins JB, Szczepanik P, Gould JB, KJein P, Lester R. Bile salt metabolism in the human premature infant. Gastroenterology 1975; 69:706-13.

12. Hanna IM, Nawarete DA, Husu FA. Calcium-fatry acid absorprion in rem infants fed human millk and prepared formulas simularing human milk. Pediatrics 1970; 45: 21 6-24.

13. Burtis CA. Ashwood ER (1999). Tietz Texbook of Clinical Chemistry, $3^{\text {th }}$ ed. Saunders, New York.

14. Lembke B, Braden B, Stein J. Diagnosis of Steatorrhea. Z Gastroenterol 1994;32(5):256-61.

15. Leus J, Wan Biervliet $S$, Robberecht $E$. Detection and follow up of exocrine pancreatic insufficiency in cystic fibrosis: a review. Eur J Pediatr 2000; 159:563-8.

16. Phuapradit ${ }^{\prime}$ Narang A, Mendonca P, Harris DA, Bam JD. The steatocrit: a simple method for estmating stool fat content in newborn infants. Arch Dis Child 1981;56:725-7.

17. Colombo C, Maiavacca R, Ronchi M, Consalwo E, Amoretri M, Giunta A. The steatocrit: a simple method for moniroring far malabsorption in patients with cystic fibrosis. I Pediatr Gasroencerol Nuer 1987:6:926-30.

18. Guarino A, Tarallo L, Greco L, Cesarano L, Guandalini S, Rubino A. Reference wallues of the stearocit and its modifications in diarrheal disesses. J Pediatr Gastroenterol Nutr 1992; 14 : $268-74$.

19. Walters MP, Kelleher J, Gilbert J, Litrlewood JM. Clinical monitoring of steatorrhea in cystic fibrosis. Arch Dis Child 1990; 65: 99-102.

20. Lloyd DR, Rowashdeh MO, Booth IW, Brown GA. The steatocrit: an improved procedure. Ann Clin Biochem 1992; 29(Pr5):535-40.

21. Rawashdeh MO, Lloyd DR, Puntis. JWL, Brown GA, Booth IW. Using the steatocrit to derermine optimal fat content in rmodular feeds. Arch Dis Child 1992; 67:608-12.

22. Hill $\mathbb{E}$, Bloor WR. Fat excretion. J Biol Chem 1922;53:171-8.

23. Tran M, Forget P, Van den Neucker A, Van Kreel B. Improved steatocrit results obtained by acidification of fecall homogenates are due to improved fat extraction. J Pediatr Gastroenteral Nurt $1996 ; 22: 157-60$.

24. Berinatd N. Colombo C, Corbeta C. In wirro influence of different kinds of fars on results and imprecision of classic and acid steacocrits. Clin Chem 1999; 45: $406-7$.

25. Amano ST, Josephon SA, Toskes PP. Acid steatocrit: a simple, rapid gravimetric method to decemine steatorthe Am J Gastroenterol 1997; 92:2280-4.

26. Tran TMD, Van den Neucker A, Hendriks JJE, Forger P, Forger P. Role of lansoprazole in children with cystic fibrosis: evidence for improved fat absorption and nutritional status.

27. Hendriks J], Kester AD, Donckerwolcke R. Forget PP, Wouters EF. Changes in pulmonary hyperinflation and bronchial hyperresponsiveness following treatment with lansoprazole in children with cystic fibrosis. Pediatr Pulmonol 2001; 31:59.66.

28. Kalivianakis M, Minich DM, Bijleweld CMA, Aalderen wan WMC. Stellaard F, Laseur M, Vonk R. Vertkade H J. Fat malabsorption in cystic fibrosis patients receiving enzyme replacement therapy is due to impaired intestinal uptake of long-chain fary acids. An I Clin Nutr 1999; 69: 127-34.

29. Nousia-Arvanitalkis S, Karagiozoglou-Lamboudes T, Aggouridaki C, Malaka-Lambrellis E, Galli-Tsinopoulou A, Xefreri M. Infuence of jejunal morphology changes on exocrine pancreatic funcrion in celiac disease. J Pediatr Gastroenterol Nutr 1999; 29:81-5. 


\section{Summary}

Excessive dietary fat consumprion is considered to be the most important cause of vascular diseases and these are associated with a high mortality rate. However fat is the most important source of energy in our diet. Fat is essential for the energy supply of the growing child, acts as a vehicle for fat-soluble vitamins and is a source of essential fatty acids. Fars are responsible for various important physiological processes.

Children fail to thrive as the intake, the digestion and/or absorption of fats are insufficient.

The introduction gives an overview of the fat digestion and absorption by the enterocyte so for as it is known today. Different causes of increased faecal fat loss are listed. Usable methods for determining faecal fat are described: the gravimetric method, the chemical titrimerric method, the method of Jeejeebhoy, the microscopic method, the reflectance method, the magnetic resonance, the steatocrit method. Furthermore currently used fat absorprion tests are described: determination of serum triglycerides and the fat loading test, determination of serum $B$-carotene, the vitamin-A-test, fat loading tests with radioactive or isotope marked fats.

In chapter 2 the amelioration of the steatocrit method by acidification is described. A better extraction of fats is achieved by acidifying of the faecal homogenate, what results in a better delineation of the different layers obtained after centrifugation of the homogenare in a haematocrit capillary. This results in a better accuracy.

Chapter 3 shows the comparison of the results of the acid steatocrit method with those obtained by currently used methods as the NIRA and the chemical titrimetric method of Van de Kamer, and these results correlated with the faecal energy obtained by bomb calorimeter.

In chapter 4 is demonstrated that similar information is obtained by a faecal sample as by a three days stool collection.

Chapter 5 indicates that the acid stearocrit method is usable from the age of 6 months and before this age faecal fat is elevated by 'physiological' reasons.

In chapter 6 the clinical usefulness of the AS method for the diagnosis of steatorrhoea is proven by comparison of the AS results with the daily faecal fat excretion and the faecal far concentration.

In chapter $7 \mathrm{AS}$ results in different groups of children are studied: heal thy children, asthma patients, children suffering from various gastrointestinal diseases and children with exocrine pancreatic insufficiency. AS results are only raised in 
this children presenting gastrointestinal diseases known to be associated wirh steatorhoea.

Chapter 8 concludes, after the general discussion, that the AS is a reliable and cinical useful method for screening and monitoring steatorrhoea in children. 


\section{Samenvatting}

Voedingsvetten worden de dag van vandaag beschouwd als de oorzaak van vasculaire aandoeningen, de meest frequente doodsoorzaak. Nochtans is ver de meest belangrijke bron van energie in onze voeding. Vet is essentieel voor het groeiende kind, als energiebron en als vehikel van vetoplosbare vitamines en bron van essentiële vetzuren. In het lichaam zijn vetten verantwoordelijk voor verschillende belangrijke fysiologische processen.

Kinderen groeien slecht als de inname, de digestie of de absorptie van vetten insufficiënt is.

De introductie geeft een overzicht van de vetvertering en de vetopname in de enterocyt, voor zover dit nu bekend is. Verschillende oorzaken van vet malabsorptie worden vermeld. De verschillende gangbare methoden om fecaal vet te bepalen worden beschreven: de gravimetrische methode, de chemische titreer methode, de methode van Jeejeebhoy, de microscopische methode, de reflecrie methode, de magnetische resonantie, de steatocrier methode. Bovendien worden de meest courante vetabsorptie testen beschreven: de bepaling van serum triglycerides and de verbelasting test, de bepaling van serum B-caroteen in het serum, vitamine $\mathrm{A}$ test, vetbelasting tests met radioactief of met stabiele isotopen gemerkte vetten.

In hoofdstuk 2 wordt de verberering van de steatocriet door aanzuren beschreven. Door aanzuren wordt een betere vetextractie bekomen in een feceshomogenaat wat resulteert in een beter afgrenzen van de verschillende lagen die worden bekomen door centrifugeren van her feceshomogenaat in een haematocriet capillair; waardoor de accuraatheid van de test verbetert.

Hoofdstuk 3 vergelijkt de resultaten van de zure steatocriet met deze van de momenteel gangbare methoden; de NIRA en de chemische titreer methode van Van de Kamer. Al de bekomen resultaten worden bovendien gecorreleerd met de fecale energie bekomen door bomcalorimetrisch onderzoek.

In hoofdstuk 4 wordt aangetoond dat een fecesmonster vergelijkbare informatie geeft als een ontlastingsverzameling van 3 dagen.

In hoofdstuk 5 wordt aangetoond dat de zure steatocriet methode bruikbaar is vanaf de leeftijd van 6 maand. Vóór deze leeftijd bestaat er een fysiologische vetverhoging in de feces.

Hoofdstuk 6 toont ons de klinische bruikbaarheid van de methode voor de diagnose van steatorrhoea door vergelijk met de dagelijkse feces vetexcrerie en de vetconcentratie. 
In boofdstuk 7 worden de zure steatocriet resultaten bekeken in verschillende groepen kinderen: gezonde kindeten, astma patiënten, kinderen met diverse gastro-enterologische aandoeningen en kinderen met exocriene pancreasinsufficiëntie. De zure steatocriet waarden zijn enkel verhoogd bij deze kinderen met aandoeningen waarbij we steatorrhoe verwachren.

In boofdstuk 8 komen we na een algemene discussie tor de conclusie dat de zure steatocriet een betrouwbare en klinisch bruikbare methode is voor de diagnose en her vervolgen van vetmalabsorptie bij kinderen. 


\section{Dankwoord}

Een thesis is zelden het werk van een enkeling en daarom is het gepast iedereen die heeft bijgedragen tot het tot stand komen van deze thesis te bedanken.

Vooreerst wil ik mijn dank richten tot mijn leermeesters die mij in navolging van Hippocrates de geneeskunde en de kindergeneeskunde hebben onderwezen.

Mijn dank gaat naar Prof. Dr. R. Donckerwolcke, mijn promotor, voor de mogelijkheid om deze thesis te verdedigen.

Mijn dank gaat uit naar mijn co-promotores Dr. P.-Ph. Forget en Dr. B. van Kreel voor hun kennis, steun, geduld en toewijding waarmee ze mij hebben begeleid doorheen de jaren dat dit werk heeft gekost.

Mijn dank gaar ook naar Dr. T.M.D. Tran voor haar vrienschap en morele steun en voor de gezellige congressen die we samen doorbrachten ter verdediging van de 'Zure Steatocrier'.

Dank aan het personeel van het laboratorium van de klinische chemie dar steeds klaar stond om mij met woord en daad te helpen.

Dank aan de ouders van onze patiënten en de ouders van de gezonde kinderen, dank aan de kinderen, voor hun bereidwilligheid om materiaal voor her onderzoek op te vangen en in te leveren.

Dank aan mijn collega's van de capaciteitsgroep Kindergeneeskunde die mij daadwerkelijk en moreel gesteund hebben.

Dank aan de collega's gastro-enterologen voor hun steun, symparhie en interesse.

Dank aan de collega's en verpleegkundigen, paramedisch personeel, onderhoudspersoneel betrokken bij de Kindergeneeskunde voor de jarenlange samenwerking.

Dank aan het administratief personeel betrokken bij de Kindergeneeskunde en wooral aan mijn secretaresse mevrouw Lea Lapré voor haar sympathie en ondersteuning.

Een speciale dank aan mijn vrienden en familie voor hun onvoorwaardelijke steun en vriendschap. 



\section{Curriculum vitae}

- Anita Maria Van den Neucker

- Geboren te Aalst (Oost-Vllaanderen, België) op 19 december 1954

- Middelbare school (Latijn-Wiskunde Humaniora) aan het Instituut Dames van Maria te Aalst tot 1972

- Geneeskunde studie aan de Rijks Universiteit te Gent 1972 - 1979

- Agnio voor Interne Geneeskunde in het Onze Lieve Vrouw Ziekenhuis te Aalst (Hoofd: Dr. E. Bougeois en Dr. P Harth) 1979 - 1980

- Kinderarts in opleiding in de Kinderkliniek C. Hooft van het Universitair Ziekenhuis te Gent 1980 - 1985 (opleiders: Prof. Dr. M.-J. Delbeke en Prof. Dr. J. Leroy)

- Fellow kinder-gastro-enterologie in het Sophia Kinderziekenhuis van het Universitair Ziekenhuis te Rotrerdam (Dr. M. Sinaasappel - Dr. J. Bouquet) 1985 $-1986$

- Kinderarts in het St. Vincentius Ziekenhuis te Antwerpen en St. Anna Ziekenhuis te Beveren-W/aas (Belgie) $1987-1988$

- Kinderarts in het centrum voor kindermishandeling: 'Kind in Nood' te Gent 1989

- Kinderarts / Kinder-gastro-enteroloog in het Academisch Ziekenhuis Maastricht sinds 1990 (Hoofd: Prof. Dr. R. Kuijten tot 1995; Prof. Dr. C. Blanco a.i. rot 1997; Prof. Dr. R. Donckerwolcke) 